\title{
Estradiol Drives the Anorexigenic Activity of Proopiomelanocortin Neurons in Female Mice
}

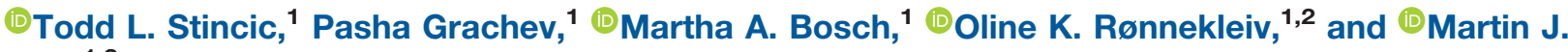 \\ Kelly ${ }^{1,2}$
}

DOI:http://dx.doi.org/10.1523/ENEURO.0103-18.2018

${ }^{1}$ Department of Physiology and Pharmacology, Oregon Health and Science University, Portland, OR 97239 and

${ }^{2}$ Division of Neuroscience, Oregon National Primate Center, Oregon Health and Science University, Beaverton, OR 97006

\begin{abstract}
Energy balance is regulated by anorexigenic proopiomelanocortin (POMC) and orexigenic neuropeptide Y/agouti-related peptide (NPY/AgRP) neurons of the hypothalamic arcuate nucleus. POMC neurons make extensive projections and are thought to release both amino acid and peptide neurotransmitters. However, whether they communicate directly with NPY/AgRP neurons is debated. Initially, using single-cell RT-PCR, we determined that mouse POMC ${ }^{\text {eGFP }}$ neurons express Slc17a6 (Vglut2) and Slc18a2 (Vmat2), but not S/c31a1 (Vgat) mRNA, suggesting glutamate and non-canonical GABA release. Quantitative (q)RT-PCR of POMC ${ }^{\text {GFP }}$ cells revealed that Vglut2 and Vmat2 expression was significantly increased in E2- versus oil-treated, ovariectomized (OVX) female mice. Since $17 \beta$-estradiol (E2) is anorexigenic, we hypothesized that an underlying mechanism is enhancement of POMC signaling. Therefore, we optogenetically stimulated POMC neurons in hypothalamic slices to examine evoked release of neurotransmitters onto NPY/AgRP neurons. Using brief light pulses, we primarily observed glutamatergic currents and, based on the paired pulse ratio (PPR), determined that release probability was higher in E2- versus oil-treated, OVX female, congruent with increased Vlgut2 expression. Moreover, bath perfusion of the Gq-coupled membrane estrogen receptor (ER) agonist STX recapitulated the effects of E2 treatment. In addition, high-frequency (20 $\mathrm{Hz}$ ) stimulation generated a slow outward current that reversed near $\mathrm{E}_{\mathrm{k}+}$ and was antagonized by naloxone, indicative of $\beta$-endorphin release. Furthermore, individual NPY/AgRP neurons were found to express Oprm1, the transcript for $\mu$-opioid receptor, and DAMGO, a selective agonist, elicited an outward current. Therefore, POMC excitability and neurotransmission are enhanced by E2, which would facilitate decreased food consumption through marked inhibition of NPY/AgRP neurons.
\end{abstract}

Key words: estrogen; obesity; sex differences; STX

\section{Significance Statement}

Proopiomelanocortin (POMC) neurons of the hypothalamic arcuate nucleus sense the energy state of an animal and regulate satiety to maintain homeostasis. Neuropeptide Y/agouti-related peptide (NPY/ AgRP) neurons also participate in energy balance, but instead drive hunger. Disruptions in this circuit can promote the development of obesity, which frequently occurs during menopause due to the loss of estrogens. The primary female sex hormone, $17 \beta$-estradiol (E2) exerts an anorexigenic effect, decreasing food intake and increasing activity. These behavioral changes are mediated, in part, through inhibition of NPY/AgRP and potentiation of POMC signaling. For the first time, we report that POMC neurons provide direct input to NPY/AgRP neurons primarily through glutamate and $\beta$-endorphin release. Furthermore, E2 enhances POMC neurotransmission to inhibit NPY/AgRP neurons. 


\section{Introduction}

$17 \beta$-estradiol (E2) is involved in the regulation of appetite, energy expenditure, body weight and adipose tissue deposition/distribution in females (Milewicz et al., 2000; Geary, 2001). During hypoestrogenic states (e.g., menopause) women tend to decrease activity and gain body fat with the increase in adiposity correlated to the decline in endogenous estrogens (Carr, 2003; Augoulea et al., 2005; Jasienska et al., 2005). In rodent models, ovariectomy (OVX) induces an increase in food intake and a decrease in ambulatory and wheel running activities, all of which are reversed with E2 replacement (Colvin and Sawyer, 1969; Ahdieh and Wade, 1982; Shimomura et al., 1990; Asarian and Geary, 2002; Qiu et al., 2006). The effect of E2 on ingestive behavior is mediated both by attenuating hunger and enhancing satiety. Within the arcuate nucleus of the hypothalamus $(\mathrm{ARH})$, orexigenic neuropeptide Y/agoutirelated peptide (NPY/AgRP) and anorexigenic proopiomelanocortin (POMC) neurons are critical to energy balance. Optogenetic activation of NPY/AgRP neurons drives hunger, whereas similar stimulation of POMC neurons decreases consumption (Aponte et al., 2011). These populations maintain homeostasis by monitoring and responding to circulating indicators of energy state (e.g., blood glucose, leptin, insulin, and ghrelin), which is possible due to their proximity to the 3rd ventricle and median eminence, a circumventricular organ (Broadwell et al., 1983; Norsted et al., 2008).

The divergent actions of E2 and other hormones (Elias et al., 1999; Qiu et al., 2014) on NPY/AgRP and POMC neurons are well established, and these ARH neurons clearly act in an antagonistic fashion on downstream targets, as $\mathrm{AgRP}$ is an endogenous antagonist of melanocortin receptors (Ollmann et al., 1997). Yet, the existence of direct connections between these two populations have been debated. Only a single study has specifically probed connectivity, finding NPY/AgRP to POMC inputs but not the reciprocal connection (Atasoy et al., 2012). However, it must be noted that low-frequency/constant stimulation was used, the internal solution was biased to measure GABAergic responses, and the actual number of cells recorded was low. The first distinction is important, as high-frequency $(2 \mathrm{~Hz})$ optogenetic stimulation can release glutamate that is excitatory on POMC and inhibitory on NPY/AgRP neurons through differential expression of postsynaptic metabotropic glutamate receptors (Nestor et al., 2016). Also, while NPY/

Received March 14, 2018; accepted July 2, 2018; First published July 17, 2018.

The authors declare no competing financial interests.

Author contributions: T.L.S., O.K.R., and M.J.K. designed research; T.L.S., P.G., O.K.R., and M.A.B. performed research; T.L.S., P.G., and M.A.B. analyzed data; T.L.S., O.K.R., and M.J.K. wrote the paper.

This work was supported by National Institutes of Health Grants R01NS38809 (to M.J.K.), R01-NS43330 (to O.K.R.), and R01-DK68098 (to M.J.K. and O.K.R.), and P30 NS061800 (to Sue Aicher).

Correspondence should be addressed to Dr. Todd L. Stincic or Dr. Martin J. Kelly at E-mail: stincic@ohsu.edu or kellym@ohsu.edu.

DOI:http://dx.doi.org/10.1523/ENEURO.0103-18.2018

Copyright (C) 2018 Stincic et al.

This is an open-access article distributed under the terms of the Creative Commons Attribution 4.0 International license, which permits unrestricted use, distribution and reproduction in any medium provided that the original work is properly attributed.
AgRP neurons receive GABAergic input from multiple sources, one of which may be POMC neurons, POMC release of GABA is another point of contention as they do not express Vgat (Ovesjö et al., 2001; Hentges et al., 2004). Yet,

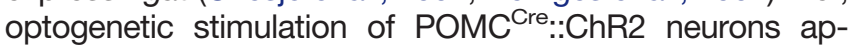
pears to evoke GABA and glutamate release, however either the number of postsynaptic neurons tested was small or their identity unknown (Atasoy et al., 2008; Dicken et al., 2012). In addition, high-frequency stimulation has been shown to release neuropeptides (Piñol et al., 2012; Kempadoo et al., 2013; Walsh et al., 2014; Apergis-Schoute et al., 2015; Qu et al., 2016), and $\beta$-endorphin input from POMC neurons could dampen NPY/AgRP neuronal activity in fed states (Yang et al., 2011). $\beta$-Endorphin binds to $\mu$-opioid receptors, which activates $G$ protein-coupled inwardly rectifying $\mathrm{K}^{+}$(GIRK) channels to hyperpolarize $\mathrm{ARH}$ neurons (Kelly et al., 1990; Slugg et al., 2000; Pennock and Hentges, 2011). If peptide release is the predominant form of POMC to NPY/AgRP neurotransmission then previous studies could have easily overlooked this putative synapse. Also, perhaps the steroid or energy state of the animal is critical to observe certain ARH interactions, and we already know NPY/AgRP projections are highly plastic (Pinto et al., 2004), a trait potentially shared by neighboring POMC neurons.

Although there has been a concerted effort to elucidate the effects of ionotropic and metabotropic receptor agonists on POMC and NPY/AgRP neurons over the past twenty-five years, the postsynaptic effects of evoked amino acid neurotransmitter release is only just emerging with the advent of optogenetics (Atasoy et al., 2008; Dicken et al., 2012; Rau and Hentges, 2017). Furthermore, nothing is known about the evoked release of neuropeptides or sex differences in transmission in relation to this homeostatic neurocircuit. Therefore, in the present study we targeted NPY/AgRP neurons using voltage clamp to record postsynaptic responses following low-frequency and high-frequency optogenetic stimulation of POMC ${ }^{\text {Cre:: }}$ ChR2 neurons in both male and female mice to address these questions.

\section{Materials and Methods}

\section{Animals}

Both male and female mice were used throughout this experiment. All animal procedures were conducted according to the National Institutes of Health Guide for the Care and Use of Laboratory Animals and with approval from the Oregon Health and Science University Animal Care and Use Committee. Animals were bred and housed in a specific pathogen-free area.

$\mathrm{POMC}^{\mathrm{Cre}}$ mice originally obtained from The Jackson Laboratories (RRID:IMSR_JAX:005965; Balthasar et al., 2004) were crossed with either Ai32 (RRID:IMSR_JAX: 012569; Madisen et al., 2012) or NPYhrGFP transgenic mice (RRID:IMSR_JAX:006417; van den Pol et al., 2009). POMC ${ }^{\text {eGFP }}$ mice (Cowley et al., 2001) were used in the single-cell RT-PCR experiments. Ai32 mice carry the ChR2 (H134R)-EYFP gene in their Gt(ROSA)26Sor locus. The gene is separated from its CAG promoter by a loxPflanked transcriptional STOP cassette, allowing its expression in a Cre-dependent manner (Madisen et al., 
2012). All colonies were maintained onsite under controlled temperature $\left(21-23^{\circ} \mathrm{C}\right)$ and photoperiod $(12 / 12 \mathrm{~h}$ light/dark cycle 6 A.M. to 6 P.M.) while receiving ad libitum food (5LOD; LabDiet) and water access. Following OVX under $2 \%$ isoflurane, mice received a subcutaneous dose of $4-5 \mathrm{mg} / \mathrm{kg}$ carprofen (Rimadyl; Pfizer Animal Health) and then recovered for one week before experimentation.

\section{AAV delivery to POMC ${ }^{\text {Cre }}$ and POMC ${ }^{\text {Cre }}$ ::NPYhrGFP}

Fourteen to 21 days (d) before each experiment, $P O M C^{\text {Cre }}$

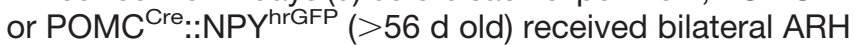
injections of a Cre-dependent adeno-associated viral (AAV; serotype 1) vector encoding ChR2-mCh (AAV1Ef1 $\alpha$-DIO-ChR2-mCherry, provided by Dr. Richard Palmiter, University of Washington, Seattle). Using aseptic technique, anesthetized $\left(1-1.5 \%\right.$ isoflurane $\left./ \mathrm{O}_{2}\right)$ mice received a medial skin incision to expose the surface of the skull. The glass pipette (\#3-000-203-G/X; Drummond Scientific) with a beveled tip (diameter $=45 \mu \mathrm{m}$ ) was filled with mineral oil, loaded with an aliquot of AAV using a Nanoject II (Drummond Scientific). ARH injection coordinates were anteroposterior (AP): $-1.18 \mathrm{~mm}$, mediolateral (ML): \pm 0.33 $\mathrm{mm}$, dorsoventral (DV): -5.80 and -5.70 (surface of the brain $\mathrm{z}=0.0 \mathrm{~mm}) ; 250 \mathrm{nl}$ of the AAV $\left(2 \times 10^{12}\right.$ particles/ $\mathrm{ml}$ ) were injected $(100 \mathrm{nl} / \mathrm{min})$ at each position, the pipette was left in place for $10 \mathrm{~min}$ after injection and then slowly retracted from the brain. The skin incision was closed using skin adhesive, and each mouse received analgesia (Rimadyl; 4-5 mg/kg, s.c.).

\section{Estrous cyclicity}

Mice were group housed with four to five mice/cage. Vaginal cytology was evaluated daily using a wet mount preparation. Briefly a small eye dropper was used to flush $0.1-\mathrm{ml}$ saline into the vagina to recover surface cells. The sample was put on a clean glass slide and observed under the microscope. Some mice follow a 4- to 5-d cycle: proestrus (nucleated epithelial cells), estrus (cornified epithelial cells), and $2 \mathrm{~d}$ of diestrus (leukocytes). However, there is much less cycle regularity in mice as compared to other rodents and they can exhibit longer or shorter cycles (Cora et al., 2015). On observing a proestrous vaginal smear, we prepared the brain slices for single-cell harvesting and measured the uterine weight to confirm the estrous cycle stage. Only females with uterine weights $>95 \mathrm{mg}$ were included.

\section{Gonadectomy}

Male gonads were left intact and all females were subjected to OVX at least $7 \mathrm{~d}$ before each experiment. Rimadyl (4-5 mg/kg, s.c.) was given immediately after surgery for relief of postoperative pain. Females received either an injection of sesame oil (50 $\mu$ l, s.c.; Sigma-Aldrich) or a priming dose $(0.125 \mu \mathrm{g} / 50 \mu \mathrm{l}$ sesame oil, s.c.) of E2 benzoate (Sigma-Aldrich) on the Friday morning following surgery. In addition, oil or a low $(0.25 \mu \mathrm{g})$ and then a high $(1.5 \mu \mathrm{g})$ dose of E2 benzoate was administered in the morning of the $2 \mathrm{~d}$ preceding experiments. Circulating levels of E2 were verified by the uterine weights $(<25 \mathrm{mg}$ for OVX and >95 mg for E2 treated) at the time of hypothalamic slice preparation (between 8:30 and 10:30 A.M.).

\section{Single-cell harvesting and PCR (scRT-PCR)}

Coronal brain sections $(240 \mu \mathrm{m})$ were cut using a Vibratome (VT-1000; Leica) and the ARH was microdissected from basal hypothalamic slices (four slices per mouse) from POMC ${ }^{\text {GFP }}$ (OVX females, $n=4$; intact males mice, $n=2$ ) and POMC ${ }^{\text {Cre::Ai32 (OVX females, } n=3 \text {; intact }}$ males $n=4$ ) for the single-cell experiments. For quantitative (q)RT-PCR experiments, intact, proestrous ( $n=4$, uterine weights $98-113 \mathrm{mg})$ or OVX female mice $(n=4)$, which were treated subcutaneously with oil (uterine weights: 19-24 mg) or E2 (uterine weights (102-111 mg), were used ( $n=5$ animals/group). Gentle trituration following incubation with protease (Sigma-Aldrich) was used to dissociate the ARH neurons. The dissociated neurons were dispersed onto a glass bottom dish and the healthy cells settled on and adhered to the glass bottom. After 15 min, the artificial CSF (aCSF) was removed, and fresh aCSF was added to the plate. This washing procedure was repeated two times. Throughout the dispersion and harvesting procedure, a constant flow $(2 \mathrm{ml} / \mathrm{min})$ of oxygenated aCSF circulated into the plate while the effluent circulated out using a peristaltic pump. The aCSF flow helped ensure fresh, oxygenated media was reaching the cells and assisted in clearing out unhealthy cells and debris from the trituration. The cells harvested were those observed to be fully intact, with one to three processes and a smooth cell membrane as visualized using an inverted microscope (DMIL; Leica) equipped with a fluorescent LED light source (X-Cite 110LED; Excelitas Technologies Corp.). Individual neurons that had adhered to the glass bottom dish were patched, and then harvested with gentle suction into the pipette using a XenoWorks Micromanipulator/Microinjector system (Sutter Instrument Company) and expelled into a siliconized 0.65-ml microcentrifuge tube containing Superscript III buffer (Invitrogen), 15-U RNasin (Promega), $10 \mathrm{mM}$ dithiothreitol (DTT), and diethylpyrocarbonate (DEPC)-treated water in a total of $5 \mu \mathrm{l}$ for ScRT-PCR (one cell/tube) or $8 \mu \mathrm{l}$ for qRT-PCR (10-cell pool/tube). After electrophysiological experiments, the cytosol of recorded cells was harvested with gentle suction into the recording pipette for post hoc identification with scRT-PCR. Each cell was expelled in a siliconized $0.65-\mathrm{ml}$ microcentrifuge tube containing the solution described above. cDNA synthesis was performed in a reaction volume of $20 \mu \mathrm{l}$ for single cells and $25 \mu \mathrm{l}$ for cell pools containing dNTPs ( $0.5 \mathrm{mM}$, Promega), random primers (100 ng per tube, Promega), anchored oligo(dT)20 primers (400 ng/tube, Invitrogen), Superscript III reversetranscriptase (100 U per tube, Invitrogen), RNAsin (15 U), DTT $(6 \mathrm{mM})$, and DEPC-treated water according to the manufactures protocol (Superscript III, Invitrogen) and stored at $-20^{\circ} \mathrm{C}$. Controls included non-fluorescent cells, aCSF harvested in the vicinity of dispersed cells, water blank, single cells reacted without reverse transcriptase, and RNA extracted from hypothalamic tissue reacted with and without reverse transcriptase. Primers for the genes that encode NPY (Npy), AgRP (Agrp), POMC (Pomc), vGluT2 (S/c17a6), vGAT (S/c32a1), $\mu$-opioid receptor (Oprm1), VMAT2 (S/c18A2), and $\beta$-actin (Actb) were de- 


\begin{tabular}{|c|c|c|c|c|c|c|c|c|}
\hline & & & & & Annealing & & iciency & \\
\hline $\begin{array}{l}\text { Gene name } \\
\text { (encodes for) }\end{array}$ & $\begin{array}{l}\text { Accession } \\
\text { number }\end{array}$ & $\begin{array}{l}\text { primer } \\
\text { location (nt) }\end{array}$ & $\begin{array}{l}\text { primer } \\
\text { location (nt) }\end{array}$ & $\begin{array}{l}\text { Product } \\
\text { length }(\mathrm{bp})\end{array}$ & $\begin{array}{c}\text { Temperature } \\
\left({ }^{\circ}\right)\end{array}$ & Slope & $r^{2}$ & $\%$ \\
\hline Npy (NPY)a & NM_023456 & $106-125$ & $268-287$ & 182 & 60 & & & \\
\hline Agrp (AgRP) ${ }^{a}$ & NM_001271806 & $397-418$ & $532-542$ & 146 & 59 & & & \\
\hline Oprm1 (muOR) & NM_001302793 & $518-537$ & $602-619$ & 102 & 57 & & & \\
\hline S/c32a1 (vGAT) ${ }^{a}$ & NM_009508 & $813-834$ & $928-949$ & 137 & 60 & & & \\
\hline Kiss1 (Kiss1) ${ }^{a}$ & NM_178260 & $64-80$ & $167-183$ & 120 & 57 & & & \\
\hline Slc18a2 (NMAT2) & NM_172523 & 1021-1041 & $1123-1143$ & 123 & 60 & -3.328 & 0.864 & 100 \\
\hline Actb $(\beta \text {-actin })^{\mathrm{b}}$ & NM_007393 & $446-465$ & $535-555$ & 110 & 60 & -3.465 & 0.996 & 95 \\
\hline
\end{tabular}

${ }^{a}$ primers used for ScRT-PCR

b primers used for qPCR.

signed using Clone Manager software (Scientific \& Educational Software). For sequences, please see Table 1.

All primers were designed to cross at least one intronexon boundary. scPCR for individual cells from either acutely dispersed cells or cells collected after recording in the slice was performed on $3 \mu \mathrm{l}$ of cDNA in a 20- $\mu$ l reaction containing GoTaq buffer ( $5 \times$, Promega), $\mathrm{MgCl}_{2}$ (2 $\mathrm{mM}$, Promega), dNTPs (0.33 mM, Promega), forward and reverse primers $(0.33 \mu \mathrm{M})$, Taq polymerase $(2 \mathrm{U}$ GoTaq, Promega), TaqStart antibody (Clontech). Fifty cycles of amplification were performed, and the PCR products were visualized with ethidium bromide on a $2 \%$ agarose gel.

qRT-PCR was performed on 4- $\mu$ l duplicate samples for the target genes vGluT2 (S/c17a6), VMAT2 (S/c18A2), vGAT (S/c32a1), $\mu$-opioid receptor (Oprm1), and on 2- $\mu$ l duplicate samples for the reference gene $\beta$-actin (Actb) using Fast SYBR Green Master Mix (Applied Biosystems) in the Quant Studio 7 Flex Real-Time PCR System (Applied Biosystems).

\section{Visualized whole-cell patch recordings}

Coronal brain slices $(240 \mu \mathrm{m})$ containing the ARH from gonadectomized or intact mice were made in an ice-cold sucrose cutting solution (see recipe below) and stored in a bubbled chamber containing aCSF (see recipe below). Whole-cell patch recordings were performed in voltage clamp and current clamp using an Olympus BX51W1 upright microscope equipped with video-enhanced, infrared-differential interference contrast (IR-DIC) and an X-Cite 120 Series fluorescent light source (Excelitas Technologies Corp.). Electrodes were fabricated from borosilicate glass (1.5 mm OD; World Precision Instruments) and filled with a normal internal solution: 128 potassium gluconate, $10 \mathrm{NaCl}, 1 \mathrm{MgCl}_{2}$, 11 EGTA, 10 HEPES, 3 ATP, and $0.25 \mathrm{GTP}$ (pH was adjusted to 7.3-7.4 with $1 \mathrm{~N} \mathrm{KOH}$, 290-300 mOsm). High chloride internal solution consisted of $140 \mathrm{mM} \mathrm{KCl}, 5 \mathrm{mM} \mathrm{MgCl} 2-6 \mathrm{H}_{2} \mathrm{O}, 1 \mathrm{mM} \mathrm{MgCl}, 0.1 \mathrm{mM}$ EGTA, $10 \mathrm{mM}$ HEPES, $5 \mathrm{mM} \mathrm{K}_{2}$-ATP, and $0.35 \mathrm{mM}$ $\mathrm{Na}_{3}$-GTP ( $\mathrm{pH}$ was adjusted to 7.3-7.4 with $\mathrm{KOH}$; $290-$ $2945 \mathrm{mOsm})$. Cesium chloride internal solution consisted of $125 \mathrm{mM} \mathrm{CsCl}, 5 \mathrm{mM} \mathrm{MgCl}, 1 \mathrm{mM}$ BAPTA, $10 \mathrm{mM}$ HEPES, $5 \mathrm{mM} \mathrm{K}_{2}$-ATP, and $0.4 \mathrm{mM} \mathrm{Na-GTP}$ ( $\mathrm{pH}$ was adjusted to 7.3-7.4 with $\mathrm{CsOH}$ ). Pipette resistances ranged from 3-5 $\mathrm{M} \Omega$. In whole-cell configuration, access resistance was $<20 \mathrm{M} \Omega$; access resistance was $80 \%$ compensated. For optogenetic stimulation, a light-induced response was evoked using an LED 470-nm blue light source controlled by a variable 2A driver (ThorLabs), with the light path delivered directly through an Olympus $40 \times$ water-immersion lens. High-fidelity response to light $(470 \mathrm{~nm})$ stimulation of POMC ${ }^{\mathrm{ARH}}$ ChR2-expressing neurons was observed, and both evoked inward currents (in voltage clamp, $\mathrm{V}(\mathrm{hold})=-60 \mathrm{mV}$ ) or depolarization (in current clamp) were measured. Electrophysiological signals were amplified using the Axopatch 200B amplifier (Molecular Devices) and digitized using the Digidata 1440A digitizer (Molecular Devices), and the data were analyzed using p-Clamp software (RRID:SCR_011323, v10.3, Molecular Devices). The liquid junction potential was corrected for all data analysis.

\section{Solutions/drugs}

A sucrose solution was used during Vibratome slicing: 2 $\mathrm{mM} \mathrm{KCl}, 1 \mathrm{mM} \mathrm{MgCl} 2-6 \mathrm{H}_{2} \mathrm{O}, 1.4 \mathrm{mM} \mathrm{NaH}{ }_{2} \mathrm{PO}_{4}, 10 \mathrm{mM}$ HEPES, $10 \mathrm{mM}$ glucose, $208 \mathrm{mM}$ sucrose, $26 \mathrm{mM}$ $\mathrm{NaHCO}_{3}, 2 \mathrm{mM} \mathrm{MgSO}_{4}-7 \mathrm{H}_{2} \mathrm{O}$, and $1 \mathrm{mM} \mathrm{CaCl}_{2}$. Standard artificial cerebrospinal fluid was used: $124 \mathrm{mM} \mathrm{NaCl}, 5$ $\mathrm{mM} \mathrm{KCl}, 1.4 \mathrm{mM} \mathrm{NaH}{ }_{2} \mathrm{PO}_{4}, 5 \mathrm{mM}$ HEPES, $10 \mathrm{mM}$ glucose, $26 \mathrm{mM} \mathrm{NaHCO}_{3}, 2 \mathrm{mM} \mathrm{MgSO}{ }_{4}-7 \mathrm{H}_{2} \mathrm{O}$, and $2 \mathrm{mM}$ $\mathrm{CaCl}_{2}$. All drugs were purchased from Tocris Bioscience unless otherwise specified. DAMGO (D-Ala2, N-MePhe4, Glyol]-enkephalin) was purchased from Peninsula Laboratories (Bachem).

\section{Immunocytochemistry (ICC) and imaging}

$\mathrm{POMC}^{\mathrm{Cre}}$ mice were injected bilaterally intra-ARH with AAV1-Ef1 $\alpha$-DIO-ChR2:mCherry as described above. Two to three weeks following the injection, mouse brains were prepared for ICC. Briefly, 2- to 3-mm coronal hypothalamic blocks were fixed by immersion in $4 \%$ paraformaldehyde, cryoprotected in $20 \%$ sucrose in Sorensen's phosphate buffer, snap-frozen at $-55^{\circ} \mathrm{C}$, sectioned coronally on a cryostat at $20 \mu \mathrm{m}$, and thaw-mounted on 
Superfrost Plus slides (Thermo Fisher Scientific). Sections were rinsed in $\mathrm{PB}(0.1 \mathrm{M}$ phosphate buffer, $\mathrm{pH}$ 7.4; all rinses were in PB for at least $30 \mathrm{~min}$ ), and then incubated for $40 \mathrm{~h}$ at $4^{\circ} \mathrm{C}$ in a mixture of rabbit anti- $\beta$-endorphin primary antibody (1:2500; a generous gift from Dr. Robert Eskay; Dave et al., 1985; Rønnekleiv et al., 1990) and goat anti-mCherry primary antibody (1:10,000; Biorbyt). Subsequently, sections were rinsed in $\mathrm{PB}$ and incubated for 2-3 $\mathrm{h}$ at room temperature with a mixture of goat antirabbit Alexa Fluor 488 secondary antibody (1:500; Life Technologies) and bovine anti-goat Cy3 (1:300; Jackson ImmunoResearch). Finally, the sections were washed in PB and coverslipped using gelvatol containing the antifading agent, 1,4-diazabicyclo(2,2)octane (DABCO; Sigma-Aldrich; $50 \mathrm{mg} / \mathrm{ml}$ ).

In select instances, at the end of the day following recordings Vibratome-sectioned slices were immersion fixed in $4 \%$ paraformaldehyde for at least $2 \mathrm{~h}$, then rinsed in PBS, mounted, and coverslipped using gelvatol containing $D A B C O$. All imaging was performed using a laser scanning confocal microscope (LSM 780; Zeiss) equipped with a $20 \times$ (numerical aperture 0.8 ) apochromatic objective and Zen software (Zeiss). For mCherry/Cy3, laser excitation was $561 \mathrm{~nm}$ and detection was $585-681 \mathrm{~nm}$. GFP/Alexa Fluor 488 laser excitation was $488 \mathrm{~nm}$ and detection was $502-571 \mathrm{~nm}$. Image processing was performed using FIJI (ImageJ) and Adobe Photoshop CC (Adobe Systems).

\section{Data analysis}

Electrophysiology

ClampFit 10.3 (Molecular Devices) and Prism (GraphPad Software) were used for analysis. Comparisons between different treatments were performed using t-tests, where appropriate. Differences were considered statistically significant if $p<0.05$. All data are expressed as mean \pm SEM.

\section{Real-time PCR}

qPCR was performed on duplicate samples from six 10-cell pools from OVX $(n=4)$, proestrous $(n=4)$, oil-treated OVX $(n=5)$, and E2-treated OVX $(n=5)$ female mice. The relative linear quantity of the target gene was calculated using the formula $2^{-\Delta \Delta C T}$ (Livak and Schmittgen, 2001). Data were expressed as an $n$-fold change in gene expression normalized to a reference gene ( $\beta$-actin) and relative to the oil-control values and quantified using an unpaired Student's $t$ test.

\section{Single-cell RT-PCR}

For determination of POMC neuronal expression of a particular transcript, 20-40 cells/animal were harvested from OVX females and intact males. The number of cells expressing each transcript was counted for rostral and caudal ARH from each animal. The group mean \pm SEM and percentage values were tabulated. Venn diagrams were generated using Venn Diagram Plotter (http://omics. pnl.gov/) to represent transcript coexpression (Fig. 1B).
Table 2. Statistics

\begin{tabular}{llcl}
\hline & Test & Post hoc Oil femalesE2 females \\
Ai32 PPR & $t$ test & 14 & 11 \\
Injected PPR $t$ test & 12 & 13 \\
STX & Paired $t$ test & 15 & \\
Slow rescue & One-way ANOVATukey's & & 5 \\
Naloxone & Paired $t$ test & & 4 \\
qRT-PCR & $t$ test & 4 & 4 (proestrus) \\
& $t$ test & 5 & 5
\end{tabular}

\section{Results}

\section{POMC neurons express machinery for glutamate and $\mathrm{GABA}$ release}

We began our examination of POMC neurotransmission using RT-PCR of single fluorescent cells from POMC ${ }^{\text {eGFP }}$ mice. This approach allowed for the sensitive and selective measurement of the transcripts supporting GABA and glutamate release. First, we chose to confirm that Slc17a6, the gene which codes for vesicular glutamate transporter 2 (vGluT2) was present. Next, we suspected that SIc31a1 (Vgat) would not be found in POMC neurons, as previous studies were unable to detect vesicular GABA transporter (vGAT) mRNA or protein in POMC neurons (Ovesjö et al., 2001; Hentges et al., 2004). We hypothesized that an alternative transporter may be mediating non-canonical GABA release. Based on a report in dopamine neurons (Tritsch et al., 2012), Slc18a2 (Vmat2), the transcript for the vesicular monoamine transporter, represented a strong candidate for this role.

Slices spanning the ARH were taken from POMC ${ }^{\text {eGFP }}$ OVX females $(n=4)$ and intact males $(n=2)$, dispersed and harvested as described in the Methods and the cells analyzed using scRT-PCR. As expected, Vgat was not detected, but in many Pomc-positive cells Vmat2 and Vglut2 mRNA were seen individually and coexpressed (Fig. 1A). For analysis, Pomc cells were segregated based on sex and relative location within the ARH (intact male rostral $=36$ neurons and caudal $=27$ neurons combined from the two males, OVX female rostral $=66$ neurons and caudal $=71$ neurons combined from the four females). These findings were not quantitative in nature but did provide a useful impression of the variability within POMC neurons. With this caveat in mind, POMC neurons from OVX females did appear to express less Vglut2 and Vmat2 mRNA than intact males (Fig. $1 A, B$ ), an indication that these transcripts were positively regulated by gonadal steroids. Therefore, to more accurately measure the effect of circulating estrogens on expression of these transporters in females, qPCR was performed on 10-cell pools (six 10 -cell pools/mouse, $n=4$ mice/group) of POMC ${ }^{\text {eGFP }}$ neurons from proestrous and OVX females. Between proestrous and OVX females we found no difference in the relative mRNA expression of Vmat2 (proestrous females: $0.94 \pm 0.28$ vs OVX females: $1.18 \pm 0.35$ ), but a 1.5 -fold higher expression of Vglut2 mRNA (proestrous vs OVX females: $1.59 \pm 0.13$ vs $1.07 \pm 0.14, p<0.05$ ). Since OVX removes all ovarian hormones, including both E2 and progesterone, we repeated the experiment with pools from E2-treated OVX females instead of intact females 
A

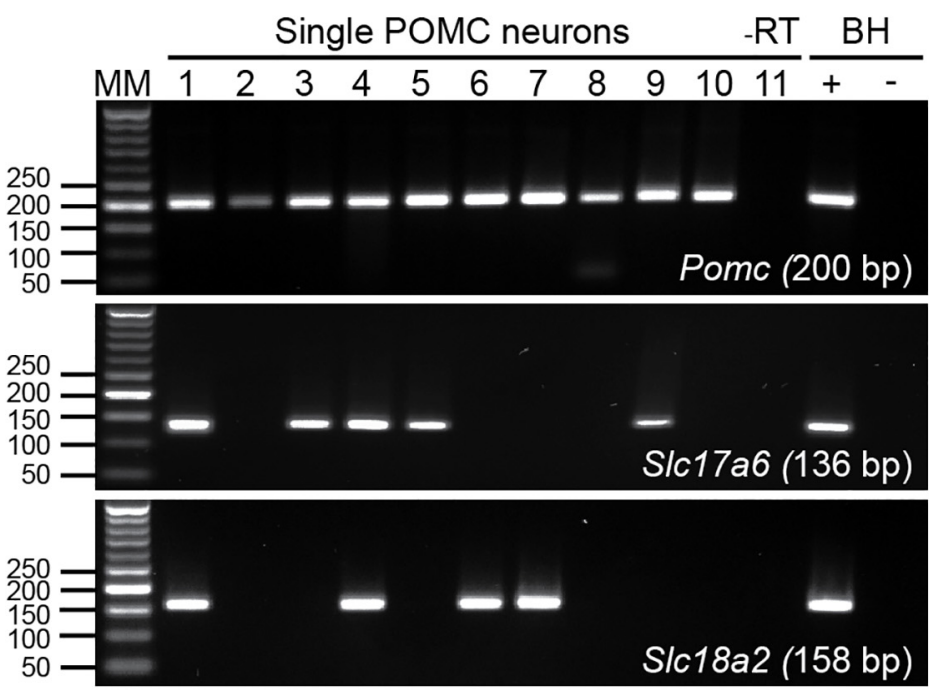

B

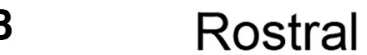

Caudal
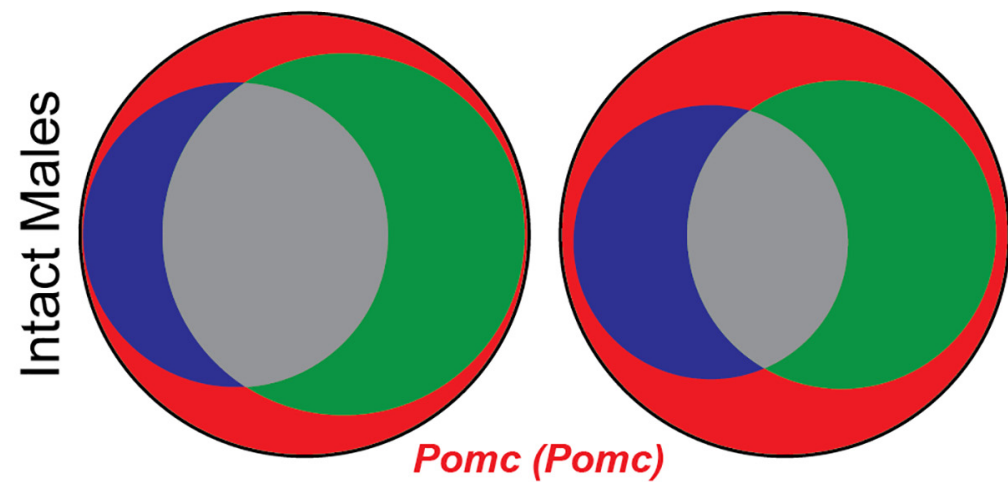

Slc17a6 (Vglut2)

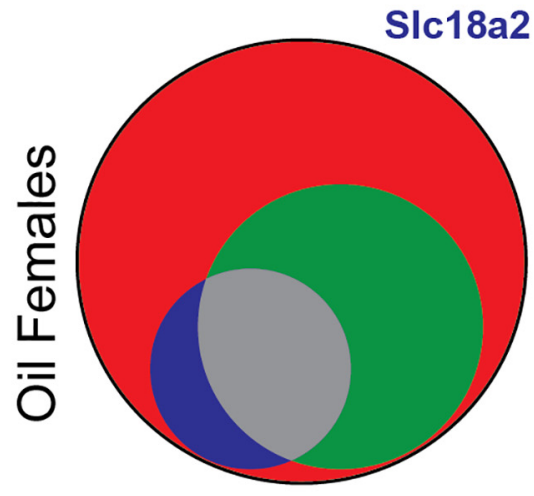

Vmat2)

C

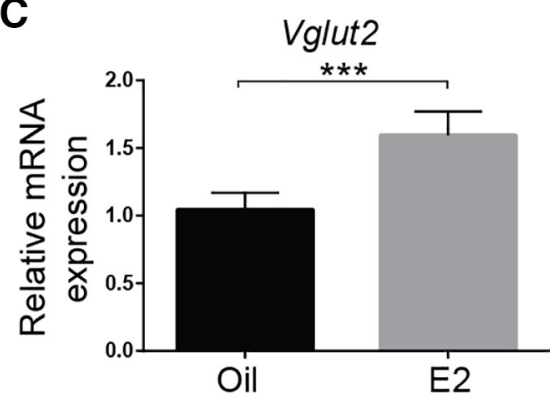

Females

Females
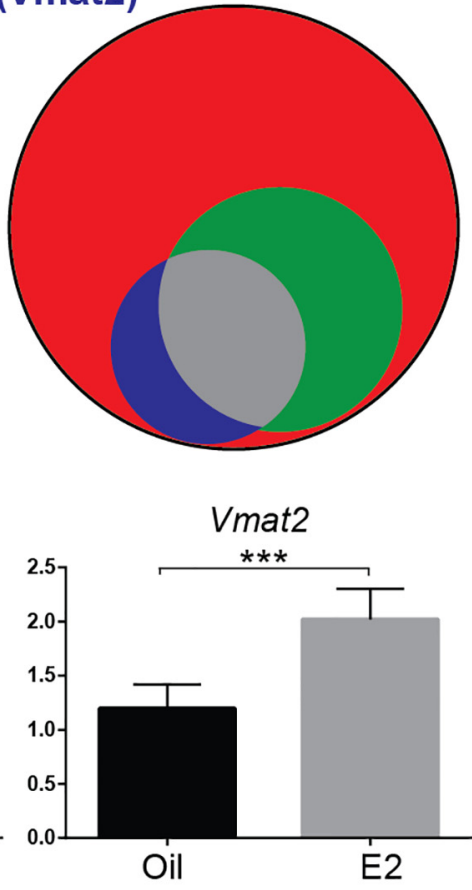

Females

Females

Figure 1. POMC neurons express mRNA for glutamate and GABA transporters. $\boldsymbol{A}$, Representative gels showing scRT-PCR detection 
continued

of S/c17a6 (Vglut2) and S/c18a2 (Vmat2), but not S/c31a1 (Vgat), in individual POMCeGFP neurons. B, Venn diagrams of relative distribution of Vglut2 and Vmat2 mRNA in harvested POMC eGFP cells from male mice $(n=2)$ and OVX females $(n=4)$. C, qRT-PCR of 10-cell POMC ${ }^{\text {GFP }}$ pools found that V glut2 andVmat2 mRNA was positively regulated by E2, as POMC ${ }^{\text {GFP }}$ neurons from E2-treated females had significantly higher relative expression compared to OVX females ( $t$ test, $* * * p<0.001, n=5$ animals/group).

(six 10-cell pools/mouse, $n=5$ mice/group). Interestingly, both Vglut2 $(p<0.001)$ and Vmat2 $(p<0.001)$ relative mRNA expression was significantly lower in the oil-treated group (Fig. 1C). Therefore, Vglut2 and Vmat2 mRNA expression, like $\beta$-endorphin levels are increased with E2 treatment (Thornton et al., 1994; Bethea and Widmann, 1996). Furthermore, as the transporter copy number is associated with release probability of glutamate, and possibly GABA, through effects on the fill state (Herman et al., 2014), one could anticipate greater POMC synaptic efficacy in E2-treated OVX females compared to oil-treated OVX counterparts.

\section{POMC input to NPY neurons}

While an early examination using channelrhodopsin (ChR2) assisted circuit mapping suggests that POMC neurons do not directly project to NPY/AgRP neurons (Atasoy et al., 2012), preliminary confocal analysis of ICC labeling of slices taken from a NPYhrGFP mouse found $\beta$-endorphin fibers made close contact with NPY neurons (Fig. 2A). Rather than a general survey of ARH interactions or POMC release, we sought to focus on the POMC to NPY synapse. Therefore, we used a POMC ${ }^{\text {Cre }}$ mouse line in conjunction with an AAV1-Ef1 $\alpha$-DIO-ChR2-mCherry virus. Due to concerns over specificity (Padilla et al., 2010), we began with immunocytochemical and histologic examinations to validate the model. AAV injections were made bilaterally into the ARH of adult POMC ${ }^{\text {Cre }}$ mice. Animals were killed two weeks later, a block containing the ARH was fixed, and $20-\mu \mathrm{m}$ sections cut on a cryostat. ICC was then performed on slides with antibodies for $\beta$-endorphin and mCherry (mCh). Confocal imaging showed that $\mathrm{mCh}$ expression was only seen in cells la- beled by the $\beta$-endorphin antibody (Fig. 2B). Next, additional AAV-injected brains $(n=2)$ were extracted, Vibratome-sectioned at $240 \mu \mathrm{m}$, and immersion fixed before being mounted on slides and coverslipped.

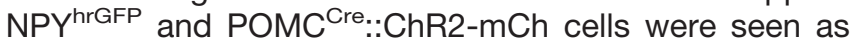
distinct populations, differing in location within the $\mathrm{ARH}$ and typical soma size (Fig. 2C). Therefore, AAV-mediated channelrhodopsin expression is specific in adult POMC ${ }^{\text {Cre }}$ mice.

Once again, $\mathrm{POMC} \mathrm{C}^{\mathrm{Cre}}$ mice were given a bilateral $\mathrm{ARH}$ injection of AAV1-Ef1 $\alpha$-DIO-ChR2-mCherry to drive expression of ChR2:mCh; Fig. 3A). During the week following injection, female mice underwent OVX and subsequently $s c$ injected with either oil or E2 while males were left intact. Electrophysiology experiments were conducted 14-28 d post-viral injection. Fluorescent POMC ${ }^{\mathrm{mCh}}$ neurons responded to $5 \mathrm{~ms}$ of $470 \mathrm{~nm}$ light with inward currents, which persisted throughout the stimulus duration (100-500 pA; Fig. 3B), and were able to easily follow $20 \mathrm{~Hz}$ stimulation (Fig. $3 C$ ), similar to what has been recently described for kisspeptin (Kiss1) neurons (Qiu et al., 2016). Cells with these direct ChR2 responses had an average input resistance of $980 \pm 150$ $\mathrm{M} \Omega(n=15)$. A lower average input resistance compared to NPY/AgRP neurons was consistent with previous findings (Smith et al., 2013; Qiu et al., 2014). The cytosol of several neurons exhibiting direct ChR2 currents were harvested and most were found to express Pomc, and none Agrp/Npy using scRT-PCR (Fig. 3D).

To assess the ability of POMC neurons to release GABA and glutamate onto NPY/AgRP neurons, we performed whole-cell voltage clamp recordings from NPY/AgRP neurons in intact males, oil-treated OVX females, and E2-treated OVX females using optogenetic stimulation.
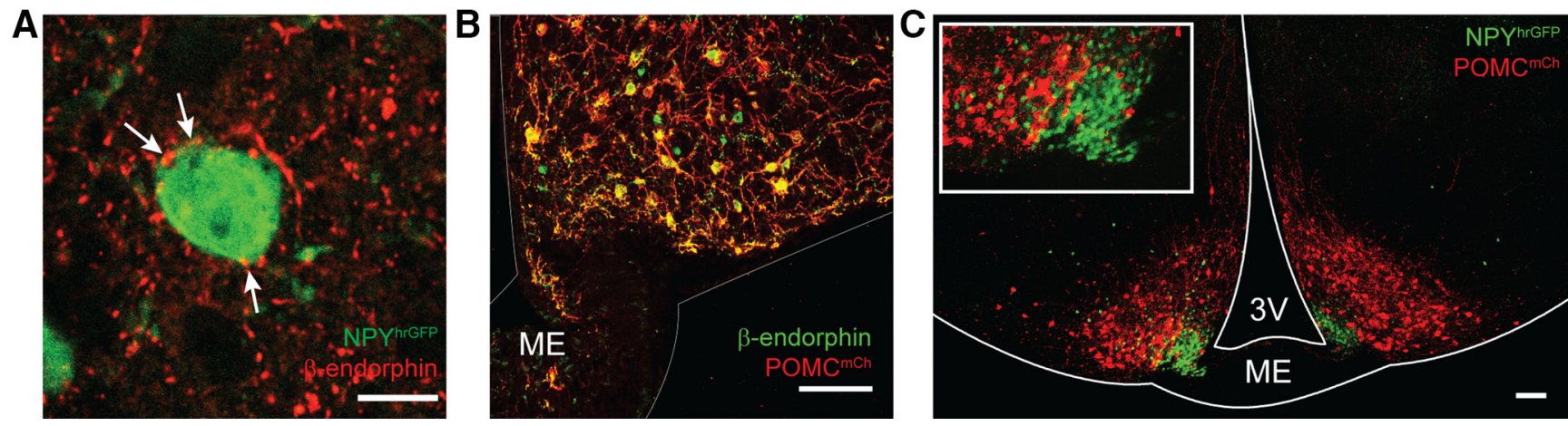

Figure 2. Virally mediated expression of channelrhodopsin in POMC ${ }^{\mathrm{Cre}}$ mice is restricted primarily to POMC neurons. $\boldsymbol{A}$, Confocal image of immunocytochemical staining using an antibody directed against $\beta$-endorphin showed close contact with NPYhrGFP neurons

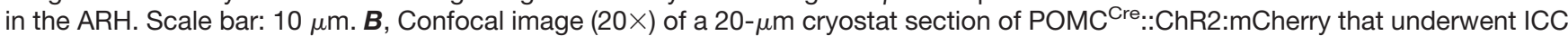
with antibodies against $\beta$-endorphin (green) and mCherry (red). High degree of colocalization indicates that virally driven ChR2mCherry expression is specific to POMC neurons. Scale bar: $100 \mu \mathrm{m}$. C , Confocal image of a $240-\mu \mathrm{m}$ coronal brain slice from a

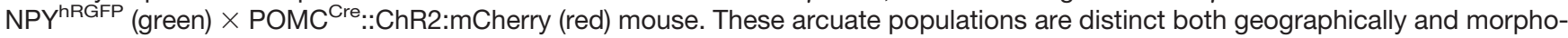
logically. Scale bar: $100 \mu \mathrm{m}$. 
A

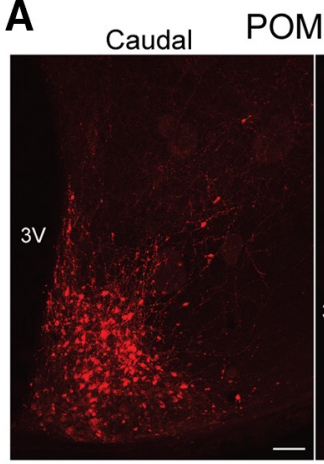

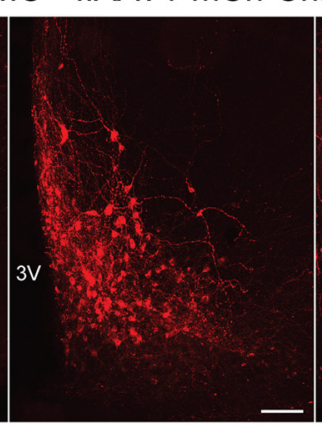

$\mathrm{POMC}^{\mathrm{Cre}}:$ :AAV1-mCh-ChR2

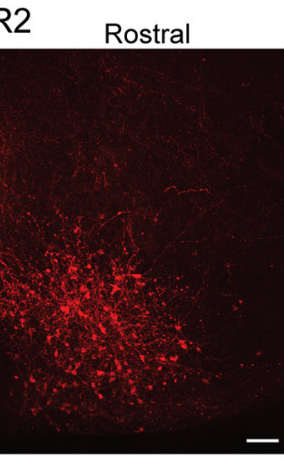

B

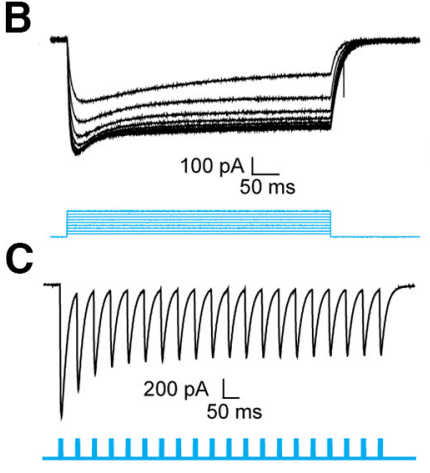

D

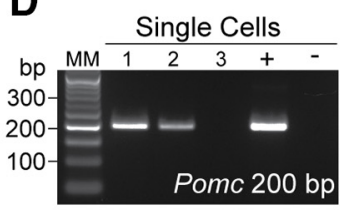

E

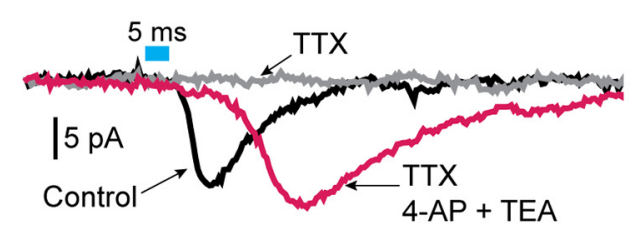

F

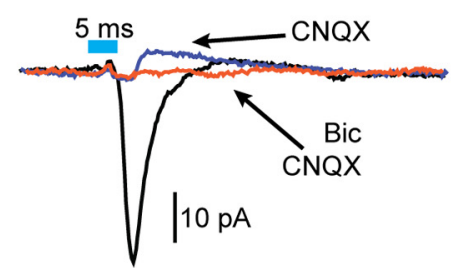

H

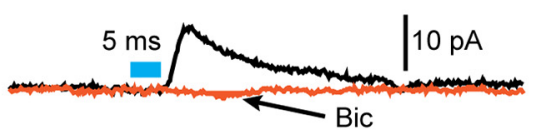

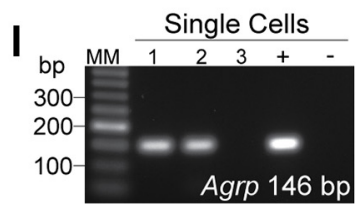

Figure 3. Optogenetic activation of POMC neurons produces postsynaptic responses in NPY/AgRP neurons. $\boldsymbol{A}$, Confocal images

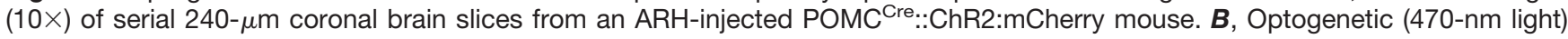
stimulation produced strong, sustained inward currents. $\boldsymbol{C}$, Channelrhodopsin currents in POMC neurons are able to faithfully follow $20-\mathrm{Hz}$ optogenetic stimulation. $\boldsymbol{D}$, Single cells harvested from fluorescent cells that responded with direct channelrhodopsin currents. $\boldsymbol{E}$, Postsynaptic nature of responses was confirmed when they were rescued from $1 \mu \mathrm{M}$ TTX after coapplication of $0.5 \mathrm{mM} 4-\mathrm{AP}$ and 7.5 mM TEA. $\boldsymbol{F}$, Both CNQX-sensitive, inward, and bicuculline-sensitive, outward currents were detected. $\mathbf{G}$, Using a standard $\mathrm{K}^{+}$ gluconate internal solution and holding $\mathrm{V}_{\mathrm{m}}$ at $-60 \mathrm{mV}$, glutamatergic currents were primarily encountered. $\boldsymbol{H}$, Less frequently, GABAergic currents could be observed. Traces are the average of 50 sweeps, blue bars representing optogenetic stimulation are 5 $\mathrm{ms}$ for postsynaptic responses. Scale bars: $100 \mu \mathrm{m}$. I, Single cells harvested following recordings which displayed a postsynaptic current. The majority could be identified as NPY/AgRP neurons post hoc for inclusion in subsequent analyses.

NPY/AgRP neurons were targeted based on either their fluorescence (hrGFP) or small soma size and proximity to the median eminence. We have found that medially located NPY/AgRP neurons can be readily segregated from the more lateral POMC neurons based on their high input resistance and low capacitance (Smith et al., 2013). In addition, when using $\mathrm{POMC}^{\mathrm{Cre}}$ mice, the cytosol from recorded neurons was harvested and used for post hoc RT-PCR confirmation of Agrp (or Npy) expression (Fig. 3/). Cells that did not test positive for Npy/Agrp and/or had an input resistance $<1 \mathrm{G} \Omega$ and capacitance $>18 \mathrm{pF}$ were excluded from analysis. To confirm the postsynaptic nature of these responses, currents were blocked by $1 \mu \mathrm{M}$ tetrodotoxin (TTX) and rescued with $0.5 \mathrm{mM} \mathrm{4-AP} \mathrm{and} 7.5$ $M$ TEA through facilitation of channelrhodopsin-mediated depolarization of nerve terminal and transmitter release (Fig. 3E; Cousin and Robinson, 2000; Petreanu et al., 2009). At $V_{m}=-60 \mathrm{mV}$, two of the recordings exhibited mixed responses following low-frequency stimulation, both inward and outward currents in a single neuron (Fig. $3 F$ ), with the inward current always preceding the outward currents. Mixed responses could have arisen from multisynaptic input or corelease, which using full field illumi- nation we could not differentiate. The corelease would be consistent with previous studies, which show that optogenetic stimulation of POMC ${ }^{\mathrm{Cre}}:$ :ChR2 neurons releases both GABA and glutamate (Atasoy et al., 2008; Dicken et al., 2012), as well as with the presence of both Vglut2 and Vmat2 transcripts in a subset of POMC neurons. However, the majority $(88.4 \%)$ of currents were inward currents and blocked by CNQX (Fig. 3G), indicating that they were glutamatergic, AMPA receptor mediated. Only $7.5 \%$ of the observed postsynaptic responses were outward and were eliminated with bath application of bicuculline (Fig. 3H). Outward currents were observed using a standard internal solution and holding the cell at $-60 \mathrm{mV}$. At times, antagonism of the inward current with CNQX and/or holding $V_{m}$ at $-10 \mathrm{mV}$ revealed a more prominent GABA response. This suggests that GABAergic currents may be masked by glutamatergic responses in the present study. If true, the tail, but not the peak, of inward currents may be reduced by the slower inhibitory input. To address this possibility, we used a high chloride internal solution in conjunction with constant bath perfusion of 50 $\mu \mathrm{M}$ D-AP5 and $10 \mu \mathrm{M}$ CNQX. Despite this procedure, we did not see an increase in the rate at which GABAergic 
A
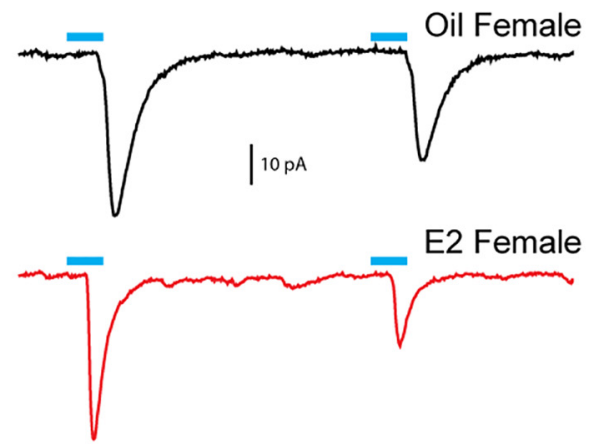

C

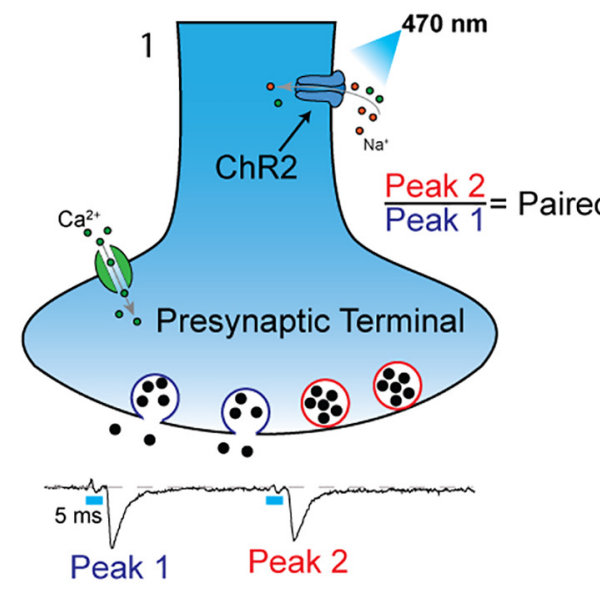

B
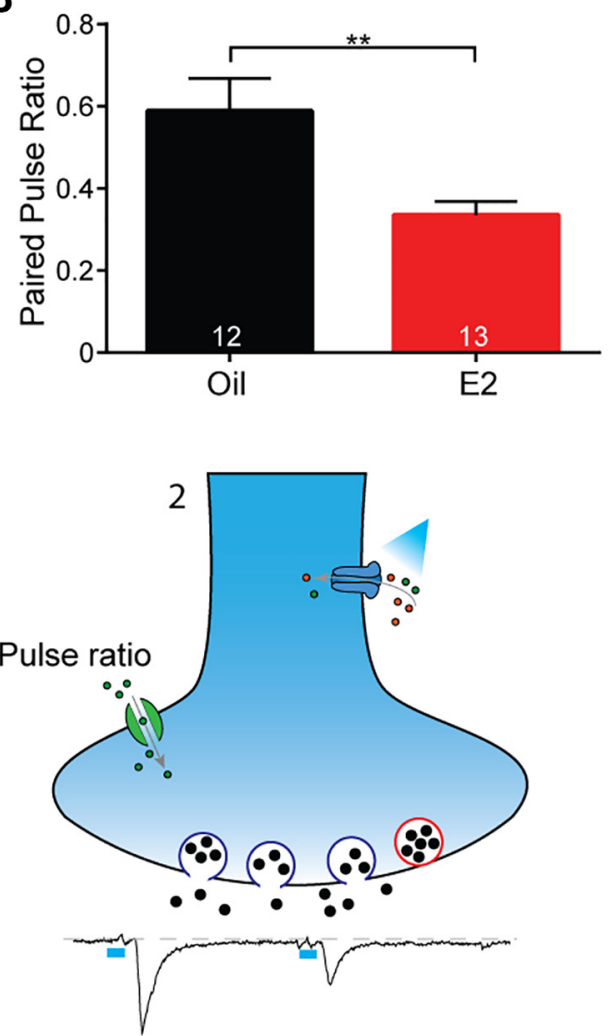

Lower values indicate higher release probability

Figure 4. Estradiol-treated OVX females have an increased probability of glutamate release onto NPY/AgRP neurons. A, Represen-

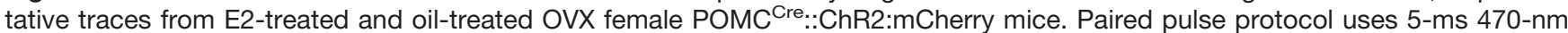
optogenetic stimulation with an interstimulus interval of $50 \mathrm{~ms}$ to measure release probability. The PPR is equal to the amplitude of peak 2 over peak 1. Lower numbers indicate a higher release probability. B, PPR is significantly lower with E2 treatment compared to oil-treated OVX mice. Traces are the average of 50 sweeps ( $t$ test, $* * p<0.01)$. $\boldsymbol{C}$, Schematic illustrating how the PPR provides a measure of neurotransmitter release probability. In terminal 1, when the two peaks are of a similar amplitude, the first stimulus did not deplete the readily releasable pool of vesicles. In terminal 2 , the first stimulus caused nearly all of the vesicles to fuse and release neurotransmitter, leaving little for the next stimulus.

currents were encountered (only one out of $34 \mathrm{ARH}$ cells). However, the high chloride greatly enhanced the frequency of spontaneous events, making detection of evoked responses difficult. Similarly, a cesium chloride internal solution caused large, non-evoked events without an appreciable improvement in the ability to detect GABAergic currents. Ultimately, however, we sought to investigate the ability of E2 to modulate neurotransmission from POMC cells and only the fast kinetics of AMPA receptors, not $\mathrm{GABA}_{\mathrm{A}}$, are suitable for assessing changes in release probability by measuring the paired pulse ratio (PPR; Kaeser and Regehr, 2014; Nestor et al., 2016).

\section{E2 increases the probability of glutamate release}

Based on the increased Vglut2 mRNA expression in E2treated OVX and intact proestrous females, we hypothesized that the anorexigenic effects of E2 were mediated, in part, through enhancement of POMC neurotransmission. Therefore, once again we administered a series of subcutaneous E2 injections to mimic the proestrous surge (Bosch et al., 2013). To measure changes in synaptic efficacy we employed a paired pulse paradigm, in which brief stimuli (5 ms, $470 \mathrm{~nm}$ light pulses) were quickly delivered with a short (50 ms) interstimulus interval (Jackman et al., 2014; Fig. 4A). The amplitude of the second peak was divided by the amplitude of the first peak to calculate the PPR. This provided a normalization that accounted for variation in expression of ChR2, allowing for both between and within subject comparisons. Lower numbers are associated with a high probability of neurotransmitter release, whereas a PPR near one represents low synaptic efficacy (Herman et al., 2014; Nestor et al., 2016). Indeed, we found that E2 treatment led to a significant decrease in the PPR [E2-treated $(n=13): 0.34 \pm$ 0.03 vs oil-treated $(n=12): 0.59 \pm 0.08, t$ test, $p<0.01$; Fig. 4B]. Therefore, E2 appears to increase the efficacy of POMC to NPY/AgRP transmission (Fig. 4C).

\section{Acute activation of $\mathrm{mERs}$ rapidly increases probability of glutamate release}

Here, we used $\mathrm{POMC}^{\mathrm{Cre}}:$ :Ai32 mice, as they did not require viral injections. A concern was that Cre-dependent expression of the ChR2::eGFP fusion protein could be driven in non-POMC neurons embryonically, with Cre 
and/or ChR2::eGFP expression persisting into adulthood (Padilla et al., 2010). Based on harvesting 270 individual fluorescent cells (intact males, $n=4$ and OVX females, $n$

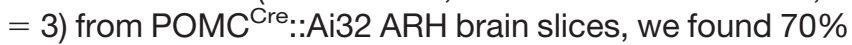
expressed POMC while $14 \%$ expressed Agrp and the remaining $16 \%$ expressed neither transcript. Therefore, the majority of neurons containing the ChR2::eGFP protein were POMC. Furthermore, by focusing on glutamatergic input we greatly reduced the possibility of studying release from non-POMC neurons as NPY/AgRP do not release glutamate (Atasoy et al., 2012). Also, PPR data from $P O M C^{\mathrm{Cre}}:: \mathrm{Ai} 32$ mice was congruent with $\mathrm{AAV}$ injected POMC ${ }^{\mathrm{Cre}}$ mice as oil-treated OVX females exhibited the largest PPR $(0.70 \pm 0.07, n=14)$, and the E2-treated OVX females showed the lowest PPR (0.28 \pm $0.04, n=11$ ).

To test the effect of acute estrogen receptor (ER) activation, we perfused $100 \mathrm{nM}$ E2 to the bath and found that the PPR was decreased within 10 min in slices taken from intact males $(n=2$; Fig. $5 A)$. Further assessing the involvement of membrane-initiated signaling of estrogen (Hammes and Levin, 2007), we used STX, a selective ER agonist that acts via a putative membrane $G_{q}$-coupled ER ( $\mathrm{G}_{\mathrm{q}}$-mER; Qu et al., 2003, 2006). STX desensitizes presynaptic POMC $\mathrm{GABA}_{\mathrm{B}}$ receptors, which is known to increase release probability through disinhibition of voltage-gated $\mathrm{Ca}^{2+}$ channels, and POMC neurons seem to universally respond to STX (Qiu et al., 2003, 2006; Conde et al., 2016). We used the longer application time compared to E2 to compensate for the slower pharmacokinetics due to the 10-fold lower concentration of STX. The higher concentration of E2 was selected to ensure rapid penetration into the slice, whereas a lower concentration was used for the more potent STX (Qiu et al., 2006). Indeed, $10 \mathrm{nM}$ STX appeared efficacious, in both intact males and OVX females, in decreasing the PPR (Fig. $5 B)$.

To confirm this effect, slices were taken from oil-treated OVX females to maximize potential acute effects of STX. E2-treated females were not tested due to the already low PPR, which would likely cause a floor effect, as E2 would bind and occlude the $G_{q}-m E R$. After 20 min of STX bath perfusion, 12 cells showed a decreased PPR that was statistically significant using a paired $t$ test $(n=15, p<$ 0.001 ; Fig. $5 C$ ). To be certain that gene transcription was not involved and a rapid, non-genomic mechanism mediated this effect, cells were pre-treated with cycloheximide for $15 \mathrm{~min}$ before application of STX to the bath (Lagrange et al., 1997). Cycloheximide prevents protein synthesis, therefore, any effects observed must be non-genomic. Indeed, STX $(n=2)$ was still able to decrease the PPR demonstrating that activation of a Gq-coupled mER is sufficient to increase release probability from POMC onto NPY/AgRP neurons (Fig. 5D).

\section{High-frequency stimulation releases beta-endorphin}

Previous reports indicate that high-frequency optogenetic stimulation can elicit peptide release (Piñol et al., 2012; Kempadoo et al., 2013; Walsh et al., 2014; ApergisSchoute et al., 2015; Qiu et al., 2016), and ARH neurons fire at $20-\mathrm{Hz}$ frequencies in vivo (Moss et al., 1975). Therefore, we implemented a $20 \mathrm{~Hz}$, high-frequency stimulus protocol to determine if optogenetics can be used to drive POMC neuropeptide transmission. As POMC neurons produce both $\alpha$-melanocyte-stimulating hormone ( $\alpha$ $\mathrm{MSH}$; excitatory, via a $\mathrm{G}_{\mathrm{s}}$-coupled receptor) and $\beta$-endorphin (inhibitory, via a $\mathrm{G} \alpha_{\mathrm{i} / \mathrm{o}}$-coupled receptor; Clark et al., 2006; Silva et al., 2001), both inward and outward currents were possible. However, optogenetic

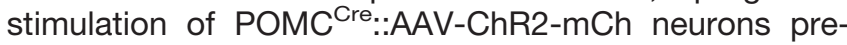
dominantly elicited outward currents (Fig. $6 A$ ) with immediate responses of $\sim 3 \mathrm{pA}$ over the $10 \mathrm{~s}$ immediately following stimulation (Fig. $6 A$ ). Maximum outward current was typically reached $1-2$ min following stimulation in NPY/AgRP neurons (10.3 $\pm 1.3 \mathrm{pA}, n=23)$, but was monitored for at least $5 \mathrm{~min}$. Interestingly, the I/V for the response reversed at $\sim \mathrm{E}_{\mathrm{K}}{ }^{+}(-82.7 \pm 1.6 \mathrm{mV}, n=7)$ and exhibited inward rectification, indicative of $\mu$-opioid receptor activation of GIRK channels (Fig. 6B). In isolation, these findings do not unequivocally demonstrate direct action of release from POMC onto NPY/AgRP neurons. Therefore, we first elicited a slow response to highfrequency optogenetic stimulation. Next, $1 \mu \mathrm{M}$ TTX was added to the bath to block voltage activated $\mathrm{Na}^{+}$channels, isolating the cell. Finally, $0.5 \mathrm{mM} 4-\mathrm{AP}$ and $7.5 \mathrm{mM}$ TEA were applied in the continued presence of TTX to block $\mathrm{K}^{+}$channels and facilitate ChR2-mediated depolarization of terminals and neurotransmitter release while preventing a multisynaptic response to highfrequency stimulation (Qiu et al., 2016). After 25 min, high-frequency stimulation was once again able to cause a slow outward current $(n=5$; Fig. $6 C)$, which is further evidence for a direct input to NPY/AgRP neurons (ANOVA, $p<0.05$ ).

To better establish the nature of the postsynaptic response, we tested to see whether naloxone, an opioid antagonist, could block or attenuate the outward current. Indeed, addition of $1 \mu \mathrm{M}$ naloxone $(n=4)$ to the bath for 20 min antagonized subsequent attempts to evoke a slow response and significantly decreased the peak outward current $(p<0.05)$, indicating that $\beta$-endorphin released from POMC neurons inhibited postsynaptic NPY/AgRP neurons via activation of opioid receptors (Fig. $6 D, E$ ). In addition, we tested for the expression of Oprm1, the transcript for $\mu$-opioid receptor, in single NPYhrGFP neurons. Oprm1 mRNA was detected in NPYhrGFP cells from E2-treated OVX females ( $40.0 \pm 4.6 \%, 25$ cells/mouse, $n$ $=3$; Fig. 7A). Therefore, at least a subset of NPY/AgRP neurons express $\mu$-opioid receptors that are activated following high-frequency stimulation of POMC neurons.

Next, we used DAMGO, a $\mu$-opioid selective agonist, to measure the effect of activation of this receptor in NPYhrGFP neurons. In current clamp, $1 \mu \mathrm{M}$ DAMGO inhibited action potential firing by $90 \%$ (Fig. $7 B$ ). For comparison to high-frequency outward EPSCs, we made voltage clamp recordings in the presence of $1 \mu \mathrm{M} T \mathrm{TX}$ while perfusing $1 \mu \mathrm{M}$ DAMGO or $10 \mu \mathrm{M}$ baclofen, observing outward currents of $\sim 10$ and 40 pA, respectively (Fig. 7C), both of which exhibited reversal potentials near $\mathrm{EK}^{+}$(Fig. 7D). While we began with $1 \mu \mathrm{M}$, to establish an effect, 

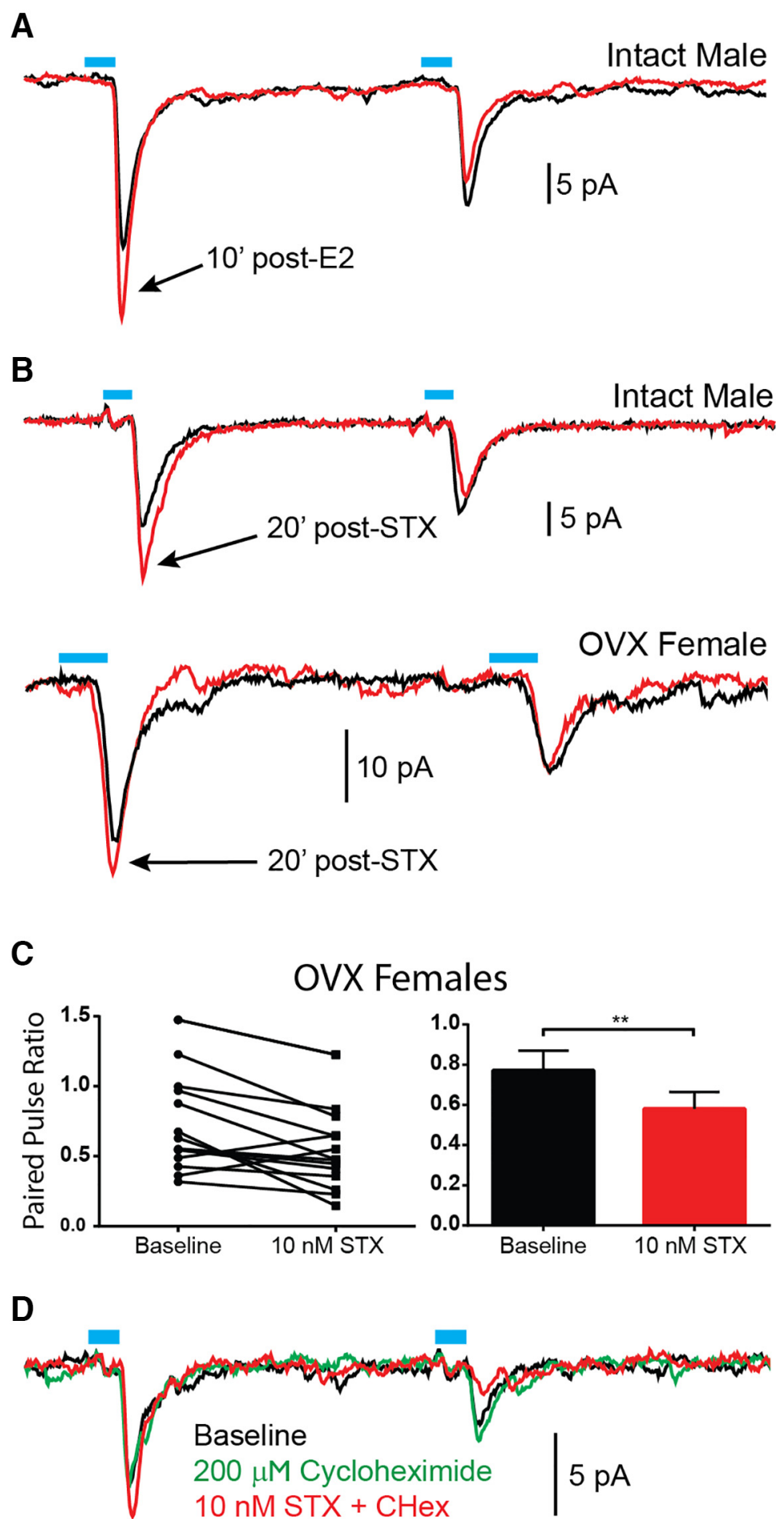

Figure 5. Acute activation of estrogen receptors (ERs) increases release probability from POMC neurons through a rapid, non-genomic mechanism. $\boldsymbol{A}$, Within $10 \mathrm{~min}$ of E2 $(100 \mathrm{nM})$ addition to the bath, the PPR is decreased, that is release probability is increased. The rapidity of this effect suggests a non-genomic mechanism of action. $\boldsymbol{B}$, Bath application of STX (10 nM), an agonist selective for a Gq-coupled membrane ER, was similarly able to decrease the PPR in cells from intact males and OVX females. $\boldsymbol{C}$. The decrease in PPR following addition of STX to the bath was statistically significant in OVX females (paired $t$ test, $* * p<0.01$ ). $\boldsymbol{D}$, Pre-treatment with cycloheximide did not prevent the effects of STX, indicating changes in transcription/translation were not necessary. Traces are the average of 50 sweeps.

$\mu$-opioid receptors display acute desensitization (Harris and Williams, 1991) and, therefore, we proceeded with lower concentrations for our examination of dose response. We made voltage clamp recordings from
NPYhrGFP neurons in the presence of $1 \mu \mathrm{M}$ TTX after addition of 100,300 , and $600(n=11)$ nM DAMGO, observing outward currents of $13.3 \pm 4.3,22.7 \pm 4.1$, and $28.8 \pm 4.5 \mathrm{pA}$, respectively. Following administration of 
A

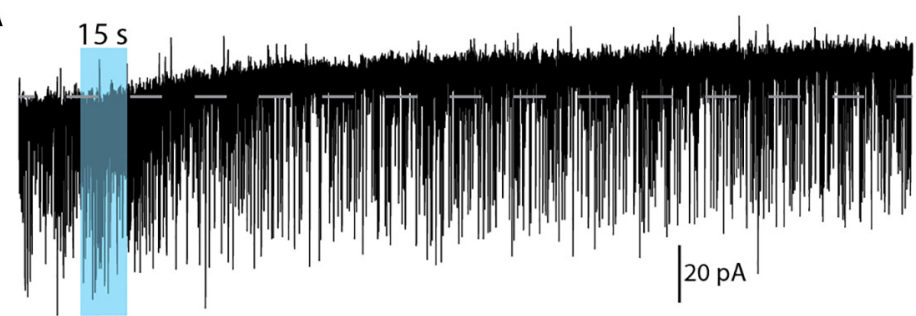

B

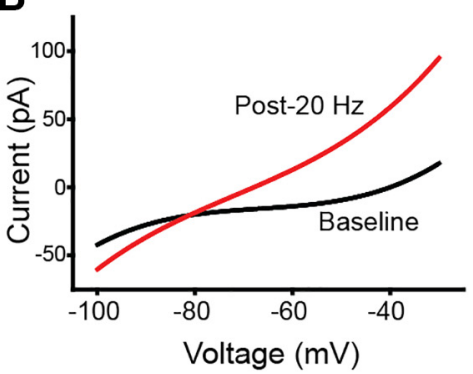

C

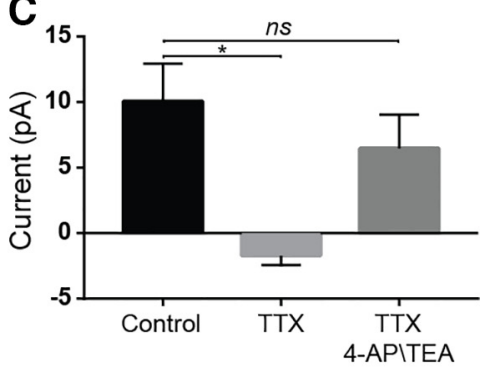

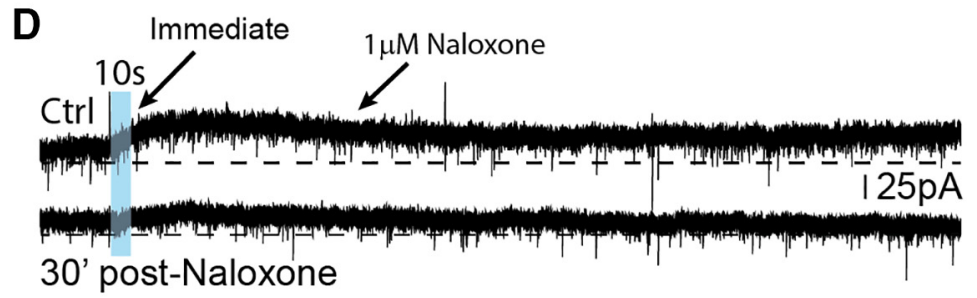

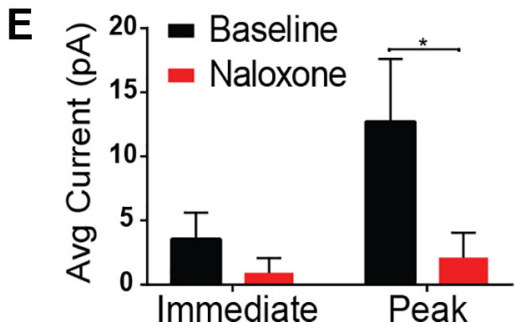

Figure 6. High-frequency stimulation of POMC neurons causes release of $\beta$-endorphin. $\boldsymbol{A}, 20 \mathrm{~Hz}$ (10 ms pulse width) for $15 \mathrm{~s}$ of 470 $\mathrm{nm}$ light could elicit a slow, long-lasting outward current. $\boldsymbol{B}$, Following high-frequency stimulation, the I/N curve crossed closer to $\mathrm{E}_{\mathrm{K}}{ }^{+}$ (average $-82.7 \pm 1.6 \mathrm{mV}$ ) and exhibited inward rectification, suggesting GIRK channels had been activated. $\boldsymbol{C}$, High-frequency response could be blocked with TTX and recovered with addition of $0.5 \mathrm{mM} 4$-AP and $7.5 \mathrm{mM}$ TEA (one-way ANOVA, $p<0.05$, Tukey's post hoc). $\boldsymbol{D}, \boldsymbol{E}$, The response to high-frequency stimulation is antagonized by bath application of $1 \mu \mathrm{M}$ naloxone, suggesting that $\beta$-endorphin is acting on postsynaptic opioid receptors. $\boldsymbol{D}$, Bar graphs showing naloxone block on the immediate and peak response following high-frequency stimulation $(n=4$, average over 10 -s period). Paired $t$ test found the peak amplitude was significantly inhibited by naloxone (paired $t$ test, $* p<0.05$ ).

$600 \mathrm{nM}$ DAMGO, $10 \mu \mathrm{M}$ baclofen was bath applied as a positive control, and any cells which did not respond were excluded from the analysis. Together, these findings strongly suggest that highly active POMC neurons, as in high E2-states (Kelly et al., 1992), will release $\beta$-endorphin onto NPY/AgRP neurons, inhibiting them through activation of $\mu$-opioid receptors. As mentioned, a small number of the high-frequency responses were slow inward currents (i.e., excitatory) presumably mediated through melanocortin signaling. This minority of responses $(n=3 / 26)$ had a peak amplitude of $-8.6 \pm 2.6 \mathrm{pA}$. However, post hoc identification by scRT-PCR found only one cell to be NPY/AgRP, with the others being Kiss1 cells. Therefore, $\beta$-endorphin is the primary peptide (95.8\%) released onto NPY/AgRP neurons during high-frequency optogenetic stimulation of POMC neurons. This suggests that POMC neuropeptides may be released in a segregated manner (Vaaga et al., 2014).

\section{Discussion}

A long-standing hypothesis has been that the anorexigenic activity of E2 is mediated largely through POMC neurons, which have been considered integral to the central control of energy homeostasis (Qiu et al., 2003, 2006; $X u$ et al., 2011). Herein, we determined that POMC neurons express S/c17a6 (Vglut2) and S/c18a2 (Vmat2), and 
A

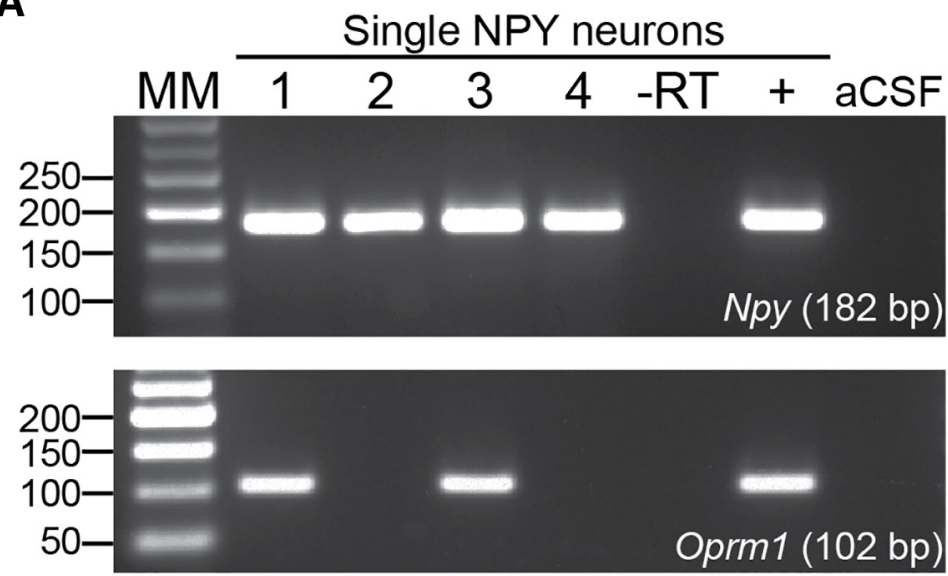

B

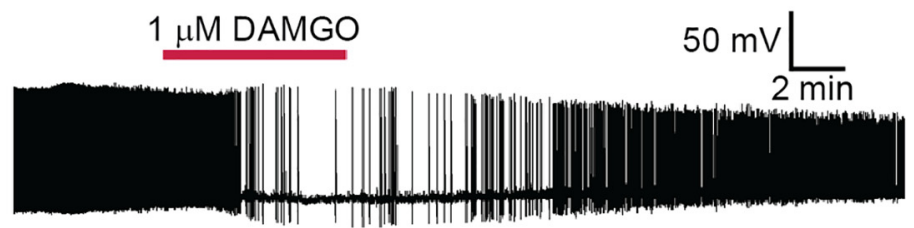

C

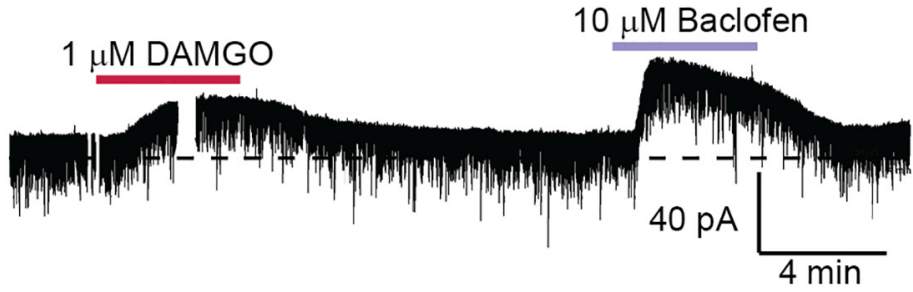

D

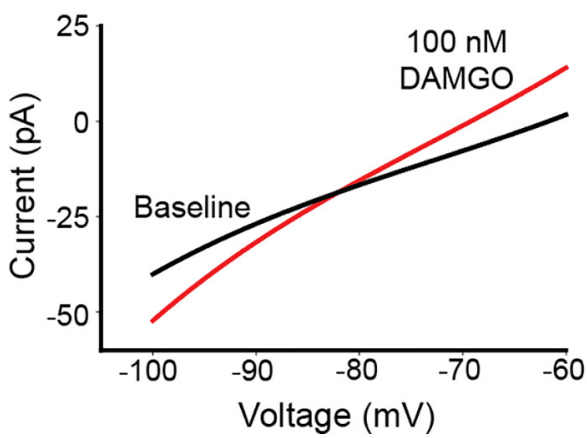

Figure 7. $\mu$-Opioid signaling in single NPY neurons. $\boldsymbol{A}$, Representative gel showing that Oprm1 the transcript for the $\mu$-opioid receptor could be detected in $\sim 40 \%$ of single NPYhrGFP neurons. $B$, Bath application of $1 \mu \mathrm{M}$ DAMGO greatly diminished the firing of action potential in an NPY neuron under current clamp. C. Both $1 \mu \mathrm{M}$ DAMGO and $10 \mu \mathrm{M}$ baclofen produced strong outward currents in voltage clamp when added to the bath. $\boldsymbol{D}$, Following bath application of DAMGO, the outward current reversed near -90 mV.

qRT-PCR of pooled POMC neurons revealed that Vglut2 and Vmat2 mRNA expression was augmented by E2 in OVX mice. E2 also increased the probability of glutamate release onto NPY/AgRP neurons following optogenetic stimulation of POMC neurons. These effects of E2 were recapitulated by bath application of the $G_{q}-m E R$ selective ligand STX, indicative that these pre-synaptic effects of E2 were mediated by a membrane ER. Moreover, highfrequency stimulation of POMC neurons released $\beta$-endorphin that inhibited NPY/AgRP neurons through activation of $\mu$-opioid receptors coupled to GIRK channels. This projection and the reciprocal connection with NPY/AgRP neurons will amplify changes in activity of each (NPY-POMC) population, as excitation of one will lead to inhibition of the other. In particular, this circuit would serve the proposed "Flip-Flop" model wherein a set point is defended to prevent unnecessary adjustments to behavior due to minor fluctuations in energy balance (Yang et al., 2011). Therefore, E2 drives the anorexigenic activity of POMC neurons by increasing their excitability 
(Roepke et al., 2011b; Smith et al., 2014) and facilitating inhibitory synaptic input to NPY/AgRP neurons.

We began our investigation by assessing the presence of transcripts necessary for GABA and glutamate release in individual POMC ${ }^{\text {GFP }}$ cells. In agreement with earlier studies, we confirmed that POMC neurons did not express Vgat mRNA (Ovesjö et al., 2001). Yet, a subset of POMC ${ }^{\text {GGFP }}$ cells in culture has been shown to release GABA and express Gad mRNA (Hentges et al., 2004). The Hentges group also documented that GAD67 ${ }^{\text {GFP }}$ is present in nearly half of fluorescent POMC neurons, particularly in the caudal ARH (Hentges et al., 2009) and that optogenetic stimulation of POMC neurons tended to produce GABAergic, more often than glutamatergic, responses in unidentified cells (Dicken et al., 2012). Therefore, we suspected the involvement of a vGATindependent mechanism of GABA release and selected VMAT2 as a likely candidate based on its support of noncanonical GABA release in dopamine neurons (Tritsch et al., 2012). Similar to POMC expression of Gad mRNA (Hentges et al., 2004), we found approximately a third of POMC ${ }^{\text {eGFP }}$ neurons expressed Vmat2 mRNA. POMC neurons therefore possess the necessary enzymes and transporters to release GABA. However, despite the presence of Vmat2 and previous reports of POMC GABA release, we were surprised to observe only infrequent IPSCs in NPY/AgRP neurons, as a GABAergic input from POMC neurons would provide a straightforward means to reduce food intake. Therefore, an effort was made to enhance and isolate IPSCs with perfusion of CNQX and D-AP5 in conjunction with different internal solutions, regardless GABAergic IPSCs remained rare. Interestingly, IPSCs were more frequent in unidentified neurons within $100 \mu \mathrm{m}$ of ChR2 expressing POMC neurons in a sagittal slice preparation (Dicken et al., 2012). Such an approach might have reduced the chances of patching NPY/AgRP neurons, but together with our findings would suggest that while POMC neurons do release GABA these projections are sent elsewhere and not onto NPY/AgRP neurons.

With regards to glutamatergic signaling, we found that about half of all POMC neurons expressed Vglut2 mRNA, and the majority of PSCs we recorded in NPY/AgRP neurons were glutamatergic. On the surface this input may appear counterproductive to the anorexigenic function of POMC neurons. However, Vglut2 mRNA expression varied with the stage of the estrous cycle and was increased with E2-treatment. Congruent with the GPCR data, E2-treated OVX females had a lower average PPR (highest synaptic efficacy) compared to oil-treated OVX females. We propose that during periods of high circulating E2, which increases the activity of POMC neurons (Kelly et al., 1992), greater release of glutamate from POMC neurons will exert an inhibitory influence on NPY/ AgRP neurons in part through activation of $\mathrm{G}_{\mathrm{i} / \mathrm{o}}$-coupled Group II/III metabotropic glutamate receptors (mGluRs), which are known to be expressed in NPY/AgRP neurons and activated by high-frequency stimulation (Nestor et al., 2016; Qiu et al., 2018). Alternatively, the reduced glutamate release could primarily activate AMPA and NMDA receptors in NPY/AgRP neurons to stimulate food intake when the concentration of circulating estrogens are low and/or the animal is in a fasted state (Liu et al., 2012).

High-frequency optogenetic stimulation can be leveraged to study peptide release (Piñol et al., 2012; Kempadoo et al., 2013; Walsh et al., 2014; Apergis-Schoute et al., 2015; Qu et al., 2016). Here we report for the first time that POMC neurons transmit peptidergic $(\beta$ endorphin) inhibitory input to NPY/AgRP neurons. Highfrequency $(20 \mathrm{~Hz})$ optogenetic stimulation for $10-15 \mathrm{~s}$ elicited a slow outward current and produced an I/V that exhibited the tell-tale characteristics of GIRK channel activation (Smith et al., 2013). While the sensitivity to naloxone suggests that the majority of this current was mediated via opioid receptors, the residual component could represent a contribution by Group II/III mGluRs since many of the cells exhibiting a high-frequency response also displayed EPSCs to low-frequency stimulation. Given that in vivo ARH POMC neurons can fire at such high frequencies (Moss et al., 1975), this likely represents physiologically relevant transmission. In addition, based on SCRT-PCR analysis, we determined that NPY/ AgRP neurons express Oprm1, the transcript for the $\mu$-opioid receptor, and DAMGO, a $\mu$-opioid selective agonist, produced a strong outward current. Together, these results indicate that the outward current in NPY/AgRP neurons following high-frequency optogenetic stimulation of POMC neurons was generated, at least in part, by $\beta$-endorphin binding to $\mu$-opioid receptors, which activated GIRK channels (Loose and Kelly, 1990). In this respect, perhaps E2 protects females from weight gain by increasing $\beta$-endorphin signaling (Thornton et al., 1994; Bethea and Widmann, 1996). This could explain why selective deletion of Vglut2 from POMC neurons only affected weight gain in males, not females, following exposure to a high-fat diet (Dennison et al., 2016).

Although chronic E2 enhanced glutamate release through increased Vglut2 mRNA expression changes, acute activation of mERs induced a similar effect (Fig. 5). Bath application of E2 and STX decreased the PPR within minutes, even when the slice was pre-treated with cycloheximide to inhibit protein synthesis. $\mathrm{GABA}_{B}$ receptors can reduce the release probability by decreasing presynaptic $\mathrm{Ca}^{2+}(\mathrm{Wu}$ and Saggau, 1995; Dittman and Regehr, 1996), activating $\mathrm{K}^{+}$channels or lowering cyclic AMP concentrations (Thompson and Gähwiler, 1992). Normally, selective activation of either $\mathrm{GABA}_{B}$ or opioid receptors causes a robust membrane hyperpolarization and cessation of action potential firing in ARH neurons including POMC neurons (Slugg et al., 2003; Kelly et al., 1990; Loose and Kelly, 1990; Pennock and Hentges, 2011). Therefore, this rapid E2/STX effect is likely the result of a $\mathrm{G}_{\mathrm{q}}$-coupled membrane ER rapidly desensitizing $\mathrm{GABA}_{\mathrm{B}}$ receptors in POMC neurons thus uncoupling it from activation of GIRK channels (Qiu et al., 2003, 2006; Fig. 8B) and enhancing POMC neurotransmission. This more rapid effect of E2 may help defend the set point against minor fluctuations in nutrients until changes in gene transcription are manifested.

Therefore, there are multiple signaling cascades engaged by E2 in hypothalamic neurons that coordinate reproduction and homeostatic processes, such as feed- 
A
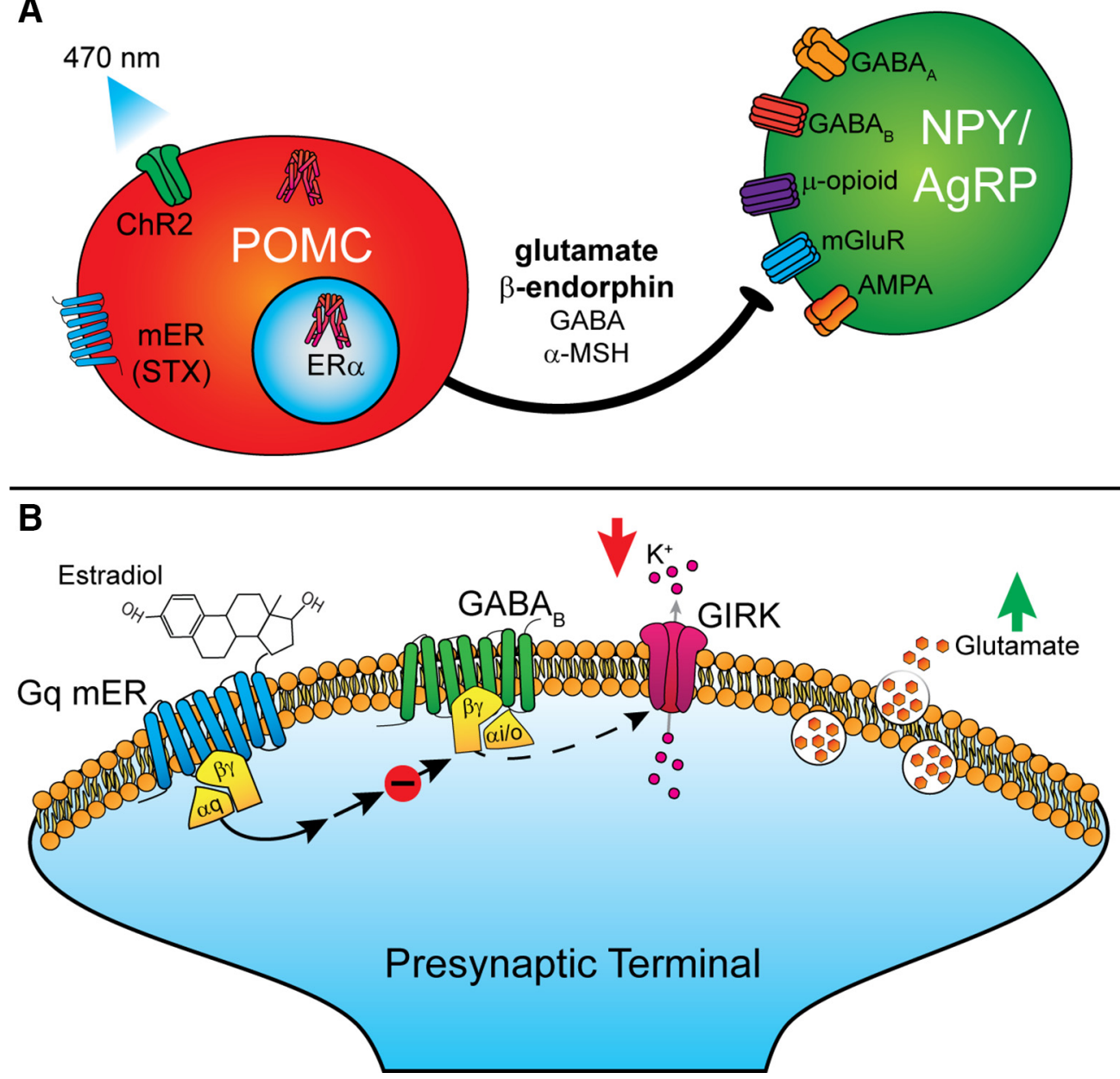

Figure 8. Signaling schematics. $\boldsymbol{A}$, Optogenetic stimulation of POMC neurons primarily evokes release of glutamate and $\beta$-endorphin onto NPY/AgRP neurons. These findings suggest release is segregated such that GABA and $\alpha$-MSH is released on to other neuronal subtypes. Acute and chronic activation of ERs increases the release probability of glutamate from POMC onto NPY/AgRP neurons. $\boldsymbol{B}$, Activation of a Gq-coupled membrane-bound ER leads to the desensitization of $\mathrm{GABA}_{\mathrm{B}}$ receptors. Decreased coupling between $\mathrm{GABA}_{\mathrm{B}}$ and GIRK channels results in greater glutamate release from the terminal.

ing behavior (Sinchak and Wagner, 2012; Kelly and Rønnekleiv, 2015; Micevych et al., 2017; Rivera and Stincic, 2018). E2 exerts potent anorectic effects through activation of POMC neurons (Kelly et al., 1992; Lagrange et al., 1994; Qiu et al., 2003, 2006) and inhibition of NPY/AgRP neurons (Roepke et al., 2011a; Smith et al., 2014), actions mediated through both membrane-initiated and nuclear signaling mechanisms. Specifically deleting $\mathrm{ER} \alpha$ in POMC neurons is sufficient to disrupt energy balance, resulting in hyperphagia and weight gain in rodents (Xu et al., 2011). Compared to oil-treated OVX female guinea pigs, rats and non-human primates, E2 upregulates Pomc mRNA and increases $\beta$-endorphin protein expression in POMC neurons (Thornton et al., 1994; Bethea and Widmann, 1996; Roepke et al., 2008), whereas E2 attenuates the orexigenic actions of NPY/AgRP neurons and suppresses its expression (Crowley et al., 1985; Pelletier et al., 2007; Santollo and Eckel, 2008).

The function of POMC neurons may be to monitor external (food and mate availability) and internal (energy balance and fertility) states, shifting motivation to maximize repro- ductive fitness (Storm and Tecott, 2005; Shadmehr et al., 2016; Fischer and O'Connell, 2017). Therefore, constant, low firing activity of POMC neurons may be insufficient or inappropriate to engage both amino acid and peptide transmission to quickly decrease food intake. Our results would suggest that high-frequency activity of POMC neurons releases $\beta$-endorphin to provide an inhibition of NPY/ AgRP activity that signals a repletion of energy stores, resetting the Flip-Flop circuit (Yang et al., 2011). In addition, we believe that our findings at this synapse will generalize to other POMC projections with differences in the expression of postsynaptic receptors and/or segregated release of neurotransmitter (Vaaga et al., 2014) determining whether the downstream target neurons are excited or inhibited. Moreover, the present findings of steroid regulation of Vglut2 mRNA expression indicate that E2 is critical for enhanced glutamatergic and peptidergic (inhibitory) signaling from POMC to NPY/AgRP neurons in the female mouse. Certainly, elucidation of this novel peptidergic (opioid) and amino acid (glutamatergic) input to NPY/AgRP neurons from POMC neurons will help 
to define this complex circuitry responsible for regulating energy metabolism and homeostasis.

Acknowledgements: We thank Dr. Richard Palmiter and Dr. Stephanie Padilla at the University of WashingtonSeattle for providing the viral vectors used in these experiments. We also thank Uyen-Vy Navarro, Ashley Connors, and J. G. Bradner for technical assistance and Dr. Jian Qiu for his helpful comments on the manuscript.

\section{References}

Ahdieh HB, Wade GN (1982) Effects of hysterectomy on sexual receptivity, food intake, running wheel activity, and hypothalamic estrogen and progestin receptors in rats. J Comp Physiol Psychol 96:886-892. Medline

Apergis-Schoute J, lordanidou P, Faure C, Jego S, Schöne C, AittaAho T, Adamantidis A, Burdakov D (2015) Optogenetic evidence for inhibitory signaling from orexin to $\mathrm{MCH}$ neurons via local microcircuits. J Neurosci 35:5435-5441. CrossRef Medline

Aponte Y, Atasoy D, Sternson SM (2011) AGRP neurons are sufficient to orchestrate feeding behavior rapidly and without training. Nat Neurosci 14:351-355. CrossRef Medline

Asarian L, Geary N (2002) Cyclic estradiol treatment normalizes body weight and restores physiological patterns of spontaneous feeding and sexual receptivity in ovariectomized rats. Horm Behav 42:461471. Medline

Atasoy D, Aponte Y, Su HH, Sternson SM (2008) A FLEX switch targets channelrhodopsin-2 to multiple cell types for imaging and long-range circuit mapping. J Neurosci 28:7025-7030. CrossRef Medline

Atasoy D, Nicholas Betley J, Su HH, Sternson SM (2012) Deconstruction of a neural circuit for hunger. Nature 488:172-177. CrossRef Medline

Augoulea A, Mastorakos G, Lambrinoudaki I, Christodoulakos G, Creatsas $G$ (2005) Role of postmenopausal hormone replacement therapy on body fat gain and leptin levels. Gynecol Endocrinol 20:227-235. CrossRef Medline

Balthasar N, Coppari R, McMinn J, Liu SM, Lee CE, Tang V, Kenny CD, McGovern RA, Chua SC, Elmquist JK, Lowell BB (2004) Leptin receptor signaling in POMC neurons is required for normal body weight homeostasis. Neuron 42:983-991. CrossRef Medline

Bethea CL, Widmann AA (1996) Immunohistochemical detection of progestin receptors in hypothalamic $\beta$-endorphin and substance $\mathrm{p}$ neurons of steroid-treated monkeys. Neuroendocrinology 63:132141. CrossRef Medline

Bosch MA, Tonsfeldt KJ, Rønnekleiv OK (2013) MRNA expression of ion channels in $\mathrm{GnRH}$ neurons: subtype-specific regulation by 17 $\beta$-estradiol. Mol Cell Endocrinol 367:85-97. CrossRef Medline

Broadwell RD, Balin BJ, Salcman M, Kaplan RS (1983) Brain-blood barrier? Yes and no. Proc Natl Acad Sci USA 80:7352-7356. Medline

Carr MC (2003) The emergence of the metabolic syndrome with menopause. J Clin Endocrinol Metab 88:2404-2411. CrossRef Medline

Clark MJ, Furman CA, Gilson TD, Traynor JR (2006) Comparison of the relative efficacy and potency of mu-opioid agonists to activate Gi/o proteins containing a pertussis toxin-insensitive mutation. J Pharmacol Exp Ther 317:858-864. CrossRef

Colvin GB, Sawyer CH (1969) Induction of running activity by intracerebral implants of estrogen in overiectomized rats. Neuroendocrinology 4:309-320. CrossRef Medline

Conde K, Meza C, Kelly MJ, Sinchak K, Wagner EJ (2016) Estradiol rapidly attenuates $\mathrm{ORL}-1$ receptor-mediated inhibition of proopiomelanocortin neurons via Gq-coupled, membrane-initiated signaling. Neuroendocrinology 103:787-805. CrossRef Medline

Cora MC, Kooistra L, Travlos G (2015) Vaginal cytology of the laboratory rat and mouse: review and criteria for the staging of the estrous cycle using stained vaginal smears. Toxicol Pathol 43: 776-793. CrossRef
Cousin MA, Robinson PJ (2000) $\mathrm{Ca}(2+)$ influx inhibits dynamin and arrests synaptic vesicle endocytosis at the active zone. J Neurosci 20:949-957. Medline

Cowley MA, Smart JL, Rubinstein M, Cerdán MG, Diano S, Horvath TL, Cone RD, Low MJ, Cerdán MG, Diano S, Horvath TL, Cone RD, Low MJ (2001) Leptin activates anorexigenic POMC neurons through a neural network in the arcuate nucleus. Nature 411:480484. CrossRef Medline

Crowley WR, Adler BA, Tessel RE, O'Donohue TL, Kalra SP (1985) Effects of ovarian hormones on the concentrations of immunoreactive neuropeptide $y$ in discrete brain regions of the female rat: correlation with serum luteinizing hormone (LH) and median eminence Ih-releasing hormone. Endocrinology 117:1151-1155. CrossRef Medline

Dave JR, Rubinstein N, Eskay RL (1985) Evidence that $\beta$-endorphin binds to specific receptors in rat peripheral tissues and stimulates the adenylate cyclase-adenosine $3^{\prime}, 5^{\prime}$-monophosphate system. Endocrinology 117:1389-1396. CrossRef Medline

Dennison CS, King CM, Dicken MS, Hentges ST (2016) Agedependent changes in amino acid phenotype and the role of glutamate release from hypothalamic proopiomelanocortin neurons. J Comp Neurol 524(6):1222-1235.

Dicken MS, Tooker RE, Hentges ST (2012) Regulation of GABA and glutamate release from proopiomelanocortin neuron terminals in intact hypothalamic networks. J Neurosci 32:4042-4048. CrossRef Medline

Dittman JS, Regehr WG (1996) Contributions of calcium-dependent and calcium-independent mechanisms to presynaptic inhibition at a cerebellar synapse. J Neurosci 16:1623-1633. CrossRef

Elias CF, Aschkenasi C, Lee C, Kelly J, Ahima RS, Bjorbaek C, Flier JS, Saper CB, Elmquist JK (1999) Leptin differentially regulates NPY and POMC neurons projecting to the lateral hypothalamic area. Neuron 23:775-786. Medline

Fischer EK, O'Connell LA (2017) Modification of feeding circuits in the evolution of social behavior. J Exp Biol 220:92-102. CrossRef Medline

Geary N (2001) Estradiol, CCK and satiation. Peptides 22:12511263. Medline

Hammes SR, Levin ER (2007) Extranuclear steroid receptors: nature and actions. Endocr Rev 28:726-741. CrossRef Medline

Harris GC, Williams JT (1991) Transient homologous mu-opioid receptor desensitization in rat locus coeruleus neurons. J Neurosci 11:2574-2581. Medline

Hentges ST, Nishiyama M, Overstreet LS, Stenzel-Poore M, Williams JT, Low MJ (2004) GABA release from proopiomelanocortin neurons. J Neurosci 24:1578-1583. CrossRef Medline

Hentges ST, Otero-Corchon V, Pennock RL, King CM, Low MJ (2009) Proopiomelanocortin expression in both GABA and glutamate neurons. J Neurosci 29:13684-13690. CrossRef Medline

Herman MA, Ackermann F, Trimbuch T, Rosenmund C (2014) Vesicular glutamate transporter expression level affects synaptic vesicle release probability at hippocampal synapses in culture. J Neurosci 34:11781-11791. CrossRef Medline

Jackman SL, Beneduce BM, Drew IR, Regehr WG (2014) Achieving high-frequency optical control of synaptic transmission. J Neurosci 34:7704-7714. CrossRef Medline

Jasienska G, Ziomkiewicz A, Górkiewicz M, Pajak A (2005) Body mass, depressive symptoms and menopausal status: an examination of the "Jolly Fat" hypothesis. Womens Heal Issues 15:145151. CrossRef Medline

Kaeser PS, Regehr WG (2014) Molecular mechanisms for synchronous, asynchronous, and spontaneous neurotransmitter release. Annu Rev Physiol 76:333-363. CrossRef Medline

Kelly MJ, Rønnekleiv OK (2015) Minireview: neural signaling of estradiol in the hypothalamus. Mol Endocrinol 29:645-657. CrossRef Medline

Kelly MJ, Loose MD, Ronnekleiv OK (1990) Opioids hyperpolarize beta-endorphin neurons via mu-receptor activation of a potassium conductance. Neuroendocrinology 52:268-275. CrossRef Medline 
Kelly MJ, Loose MD, Ronnekleiv OK (1992) Estrogen suppresses mu-opioid- and GABAB-mediated hyperpolarization of hypothalamic arcuate neurons. J Neurosci 12:2745-2750. Medline

Kempadoo KA, Tourino C, Cho SL, Magnani F, Leinninger G-M, Stuber GD, Zhang F, Myers MG, Deisseroth K, de Lecea L, Bonci A (2013) Hypothalamic neurotensin projections promote reward by enhancing glutamate transmission in the VTA. J Neurosci 33: 7618-7626. CrossRef Medline

Lagrange AH, Ronnekleiv OK, Kelly MJ (1994) The potency of muopioid hyperpolarization of hypothalamic arcuate neurons is rapidly attenuated by 17 beta-estradiol. J Neurosci 14:6196-6204.

Lagrange AH, Ronnekleiv OK, Kelly MJ (1997) Modulation of G protein-coupled receptors by an estrogen receptor that activates protein kinase A. Mol Pharmacol 51:605-612. Medline

Liu T, Kong D, Shah BP, Ye C, Koda S, Saunders A, Ding JB, Yang Z, Sabatini BL, Lowell BB (2012) Fasting activation of AgRP neurons requires NMDA receptors and involves spinogenesis and increased excitatory tone. Neuron 73:511-522. CrossRef Medline

Livak KJ, Schmittgen TD (2001) Analysis of relative gene expression data using real-time quantitative PCR and the $2^{-\Delta \Delta \mathrm{C}_{\mathrm{T}}}$ method. Methods 25:402-408. CrossRef Medline

Loose MD, Kelly MJ (1990) Opioids act at $\mu$-receptors to hyperpolarize arcuate neurons via an inwardly rectifying potassium conductance. Brain Res 513:15-23. Medline

Madisen L, Mao T, Koch H, Zhuo JM, Berenyi A, Fujisawa S, Hsu YW, Garcia AJ 3rd, Gu X, Zanella S, Kidney J, Gu H, Mao Y, Hooks BM, Boyden ES, Buzsáki G, Ramirez JM, Jones AR, Svoboda K, Han X, et al. (2012) A toolbox of Cre-dependent optogenetic transgenic mice for light-induced activation and silencing. Nat Neurosci 15:793-802. CrossRef Medline

Micevych PE, Mermelstein PG, Sinchak K (2017) Estradiol membrane-initiated signaling in the brain mediates reproduction. Trends Neurosci 40:654-666. CrossRef Medline

Milewicz A, Bidzińska B, Mikulski E, Demissie M, Tworowska U (2000) Influence of obesity and menopausal status on serum leptin, cholecystokinin, galanin and neuropeptide $Y$ levels. Gynecol Endocrinol 14:196-203. CrossRef Medline

Moss RL, Kelly M, Riskind P (1975) Tuberoinfundibular neurons: dopaminergic and norepinephrinergic sensitivity. Brain Res 89: 265-277. Medline

Nestor CC, Qiu J, Padilla SL, Zhang C, Bosch MA, Fan W, Aicher SA, Palmiter RD, Rønnekleiv OK, Kelly MJ (2016) Optogenetic stimulation of arcuate nucleus Kiss1 neurons reveals a steroiddependent glutamatergic input to POMC and AgRP neurons in male mice. Mol Endocrinol 30:630-644. CrossRef Medline

Norsted E, Gömüç B, Meister B (2008) Protein components of the blood-brain barrier (BBB) in the mediobasal hypothalamus. $J$ Chem Neuroanat 36:107-121. CrossRef Medline

Ollmann MM, Wilson BD, Yang YK, Kerns JA, Chen Y, Gantz I, Barsh GS (1997) Antagonism of Central Melanocortin receptors in vitro and in vivo by agouti-related protein. Science 278:135-138. CrossRef

Ovesjö ML, Gamstedt M, Collin M, Meister B (2001) GABAergic nature of hypothalamic leptin target neurones in the ventromedial arcuate nucleus. J Neuroendocrinol 13:505-516. Medline

Padilla SL, Carmody JS, Zeltser LM (2010) Pomc-expressing progenitors give rise to antagonistic neuronal populations in hypothalamic feeding circuits. Nat Med 16:403-405. CrossRef Medline

Pelletier G, Li S, Luu-The V, Labrie F (2007) Oestrogenic regulation of pro-opiomelanocortin, neuropeptide $\mathrm{Y}$ and corticotrophinreleasing hormone mRNAs in mouse hypothalamus. J Neuroendocrinol 19:426-431. CrossRef

Pennock RL, Hentges ST (2011) Differential expression and sensitivity of presynaptic and postsynaptic opioid receptors regulating hypothalamic proopiomelanocortin neurons. J Neurosci 31:281288. CrossRef Medline

Petreanu L, Mao T, Sternson SM, Svoboda K (2009) The subcellular organization of neocortical excitatory connections. Nature 457: 1142-1145. CrossRef Medline
Piñol RA, Bateman R, Mendelowitz D (2012) Optogenetic approaches to characterize the long-range synaptic pathways from the hypothalamus to brain stem autonomic nuclei. J Neurosci Methods 210:238-246. CrossRef Medline

Pinto S, Roseberry AG, Liu H, Diano S, Shanabrough M, Cai X, Friedman JM, Horvath TL (2004) Rapid rewiring of arcuate nucleus feeding circuits by leptin. Science 304:110-115. CrossRef Medline Qiu J, Bosch MA, Tobias SC, Grandy DK, Scanlan TS, Ronnekleiv OK, Kelly MJ (2003) Rapid signaling of estrogen in hypothalamic neurons involves a novel G-protein-coupled estrogen receptor that activates protein kinase C. J Neurosci 23:9529-9540. Medline

Qiu J, Bosch MA, Tobias SC, Krust A, Graham SM, Murphy SJ, Korach KS, Chambon P, Scanlan TS, Rønnekleiv OK, Kelly MJ (2006) A G-protein-coupled estrogen receptor is involved in hypothalamic control of energy homeostasis. J Neurosci 26:56495655. CrossRef Medline

Qiu J, Rivera HM, Bosch MA, Padilla SL, Stincic TL, Palmiter RD, Kelly MJ, Ronnekleiv OK (2018) Estrogenic-dependent glutamatergic neurotransmission from kisspeptin neurons governs feeding circuits in females. eLife, in press.

Qiu J, Zhang C, Borgquist A, Nestor CC, Smith AW, Bosch MA, Ku S, Wagner EJ, Rønnekleiv OK, Kelly MJ (2014) Insulin excites anorexigenic proopiomelanocortin neurons via activation of canonical transient receptor potential channels. Cell Metab 19:682693. CrossRef

Qiu J, Nestor CC, Zhang C, Padilla SL, Palmiter RD, Kelly MJ, Rønnekleiv OK (2016) High-frequency stimulation-induced peptide release synchronizes arcuate kisspeptin neurons and excites $\mathrm{GnRH}$ neurons. Elife 5. CrossRef

Rau AR, Hentges ST (2017) The relevance of AgRP neuron-derived GABA inputs to POMC neurons differs for spontaneous and evoked release. J Neurosci 37:7362-7372. CrossRef Medline

Rivera HM, Stincic TL (2018) Estradiol and the control of feeding behavior. Steroids 133:44-52.

Roepke TA, Xue C, Bosch MA, Scanlan TS, Kelly MJ, Rønnekleiv OKOK (2008) Genes associated with membrane-initiated signaling of estrogen and energy homeostasis. Endocrinology 149:61136124. CrossRef

Roepke TA, Qiu J, Smith AW, Rønnekleiv OK, Kelly MJ (2011a) Fasting and $17 \beta$-estradiol differentially modulate the M-current in neuropeptide $Y$ neurons. J Neurosci 31:11825-11835. CrossRef Medline

Roepke TA, Rønnekleiv OK, Kelly MJ (2011b) Physiological consequences of membrane-initiated estrogen signaling in the brain. Front Biosci 16:1560-1573. CrossRef

Rønnekleiv OK, Loose MD, Erickson KR, Kelly MJ (1990) A method for immunocytochemical identification of biocytin-labeled neurons following intracellular recording. Biotechniques 9:432-438. Medline

Santollo J, Eckel LA (2008) Estradiol decreases the orexigenic effect of neuropeptide $\mathrm{Y}$, but not agouti-related protein, in ovariectomized rats. Behav Brain Res 191:173-177. CrossRef Medline

Shadmehr R, Huang HJ, Ahmed AA (2016) A representation of effort in decision-making and motor control. Curr Biol 26:1929-1934. CrossRef Medline

Shimomura Y, Shimizu H, Takahashi M, Sato N, Uehara Y, Fukatsu A, Negishi M, Kobayashi I, Kobayashi S (1990) The significance of decreased ambulatory activity during the generation by long-term observation of obesity in ovariectomized rats. Physiol Behav 47: 155-159. Medline

Silva RM, Hadjimarkou MM, Rossi GC, Pasternak GW, Bodnar RJ (2001) Beta-endorphin-induced feeding: pharmacological characterization using selective opioid antagonists and antisense probes in rats. J Pharmacol Exp Ther 297:590-596. Medline

Sinchak K, Wagner EJ (2012) Estradiol signaling in the regulation of reproduction and energy balance. Front Neuroendocrinol 33:342363. CrossRef Medline

Slugg RM, Hayward MD, Ronnekleiv OK, Low MJ, Kelly MJ (2000) Effect of the $\mu$-opioid agonist DAMGO on medial basal hypotha- 
lamic neurons in beta-endorphin knockout mice. Neuroendocrinology 72:208-217. CrossRef Medline

Slugg RM, Zheng SX, Fang Y, Kelly MJ, Rønnekleiv OK (2003) Baclofen inhibits guinea pig magnocellular neurones via activation of an inwardly rectifying K+ conductance. J Physiol 551:295-308. CrossRef Medline

Smith AW, Bosch MA, Wagner EJ, Rønnekleiv OK, Kelly MJ (2013) The membrane estrogen receptor ligand STX rapidly enhances GABAergic signaling in NPY/AgRP neurons: role in mediating the anorexigenic effects of 17 -estradiol. Am J Physiol Endocrinol Metab 305:E632-E640. CrossRef

Smith AW, Rønnekleiv OK, Kelly MJ (2014) Gq-mER signaling has opposite effects on hypothalamic orexigenic and anorexigenic neurons. Steroids 81:31-35. CrossRef Medline

Storm EE, Tecott LH (2005) Social circuits: peptidergic regulation of mammalian social behavior. Neuron 47:483-486. CrossRef Medline

Thompson SM, Gähwiler BH (1992) Comparison of the actions of baclofen at pre- and postsynaptic receptors in the rat hippocampus in vitro. J Physiol 451:329-345. Medline

Thornton JE, Loose MD, Kelly MJ, Rönnekleiv OK (1994) Effects of estrogen on the number of neurons expressing $\beta$-endorphin in the medial basal hypothalamus of the female guinea pig. J Comp Neur 341:68-77. CrossRef Medline

Tritsch NX, Ding JB, Sabatini BL (2012) Dopaminergic neurons inhibit striatal output through non-canonical release of GABA. Nature 490:262-266. CrossRef Medline
Vaaga CE, Borisovska M, Westbrook GL (2014) Dual-transmitter neurons: functional implications of co-release and cotransmission. Curr Opin Neurobiol 29:25-32. CrossRef Medline

van den Pol AN, Yao Y, Fu L-Y, Foo K, Huang H, Coppari R, Lowell BB, Broberger C (2009) Neuromedin B and gastrin-releasing peptide excite arcuate nucleus neuropeptide $Y$ neurons in a novel transgenic mouse expressing strong Renilla green fluorescent protein in NPY neurons. J Neurosci 29:4622-4639. CrossRef

Walsh JJ, Friedman AK, Sun H, Heller EA, Ku SM, Juarez B, Burnham VL, Mazei-Robison MS, Ferguson D, Golden SA, Koo JW, Chaudhury D, Christoffel DJ, Pomeranz L, Friedman JM, Russo SJ, Nestler EJ, Han MH (2014) Stress and CRF gate neural activation of BDNF in the mesolimbic reward pathway. Nat Neurosci 17:2729. CrossRef Medline

Wu LG, Saggau P (1995) GABAB receptor-mediated presynaptic inhibition in guinea-pig hippocampus is caused by reduction of presynaptic $\mathrm{Ca} 2+$ influx. J Physiol 649-657. CrossRef

Xu Y, Nedungadi TP, Zhu L, Sobhani N, Irani BG, Davis KE, Zhang X, Zou F, Gent LM, Hahner LD, Khan SA, Elias CF, Elmquist JK, Clegg DJ (2011) Distinct hypothalamic neurons mediate estrogenic effects on energy homeostasis and reproduction. Cell Metab 14:453-465. CrossRef Medline

Yang Y, Atasoy D, Su HH, Sternson SM (2011) Hunger states switch a flip-flop memory circuit via a synaptic AMPK-dependent positive feedback loop. Cell 146:992-1003. CrossRef Medline 